Article

\title{
With a Little Help from My Cell Wall: Structural Modifications in Pectin May Play a Role to Overcome Both Dehydration Stress and Fungal Pathogens
}

\author{
Ariana D. Forand ${ }^{1}$, Y. Zou Finfrock ${ }^{2,3}{ }^{\text {, Miranda } \text { Lavier }^{3}{ }^{(D} \text {, Jarvis Stobbs }}{ }^{3}$, Li Qin ${ }^{4} \mathbb{D}$, Sheng Wang $^{1,5}$, \\ Chithra Karunakaran ${ }^{3}$, Yangdou Wei ${ }^{4}$, Supratim Ghosh ${ }^{6} \mathbb{D}$ and Karen K. Tanino ${ }^{1, *}$
}

1 Department of Plant Sciences, University of Saskatchewan, Saskatoon, SK S7N 5A8, Canada; adf472@usask.ca (A.D.F.); sheng.wang@usask.ca (S.W.)

2 Advanced Photo Source, Lemont, IL 60439, USA; finfrock@anl.gov

3 Canadian Light Source, Saskatoon, SK S7N 2V3, Canada; Miranda.Lavier@lightsource.ca (M.L.); jarvis.stobbs@lightsource.ca (J.S.); chithra.karunakaran@lightsource.ca (C.K.)

4 Department of Biology, University of Saskatchewan, Saskatoon, SK S7N 5E2, Canada; li.qin@usask.ca (L.Q.); yangdou.wei@usask.ca (Y.W.)

5 Department of Biochemistry, Microbiology and Immunology, University of Saskatchewan, Saskatoon, SK S7N 5E5, Canada

6 Department of Food and Bioproduct Sciences, University of Saskatchewan, Saskatoon, SK S7N 5A8, Canada; supratim.ghosh@usask.ca

* Correspondence: karen.tanino@usask.ca

check for updates

Citation: Forand, A.D.; Finfrock, Y.Z.; Lavier, M.; Stobbs, J.; Qin, L.; Wang,

S.; Karunakaran, C.; Wei, Y.; Ghosh,

S.; Tanino, K.K. With a Little Help

from My Cell Wall: Structural

Modifications in Pectin May Play a

Role to Overcome Both Dehydration

Stress and Fungal Pathogens. Plants

2022, 11, 385. https://doi.org/

$10.3390 /$ plants 11030385

Academic Editors: Penélope

García-Angulo and Asier

Largo-Gosens

Received: 14 December 2021

Accepted: 26 January 2022

Published: 30 January 2022

Publisher's Note: MDPI stays neutral with regard to jurisdictional claims in published maps and institutional affiliations.

Copyright: (c) 2022 by the authors. Licensee MDPI, Basel, Switzerland. This article is an open access article distributed under the terms and conditions of the Creative Commons Attribution (CC BY) license (https:/ / creativecommons.org/licenses/by/ $4.0 /)$.

\begin{abstract}
Cell wall structural modifications through pectin cross-linkages between calcium ions and/or boric acid may be key to mitigating dehydration stress and fungal pathogens. Water loss was profiled in a pure pectin system and in vivo. While calcium and boron reduced water loss in pure pectin standards, the impact on Allium species was insignificant $(p>0.05)$. Nevertheless, synchrotron X-ray microscopy showed the localization of exogenously applied calcium to the apoplast in the epidermal cells of Allium fistulosum. Exogenous calcium application increased viscosity and resistance to shear force in Allium fistulosum, suggesting the formation of calcium cross-linkages ("egg-box" structures). Moreover, Allium fistulosum (freezing tolerant) was also more tolerant to dehydration stress compared to Allium cepa (freezing sensitive). Furthermore, the addition of boric acid $\left(\mathrm{H}_{3} \mathrm{BO}_{3}\right)$ to pure pectin reduced water loss and increased viscosity, which indicates the formation of RG-II dimers. The Arabidopsis boron transport mutant, bor1, expressed greater water loss and, based on the lesion area of leaf tissue, a greater susceptibility to Colletotrichum higginsianum and Botrytis cinerea. While pectin modifications in the cell wall are likely not the sole solution to dehydration and biotic stress resistance, they appear to play an important role against multiple stresses.
\end{abstract}

Keywords: cell wall; pectin; calcium; boron; homogalacturonan; rhamnogalacturonan II; Botrytis cinerea; Colletotrichum higginsianum; dehydration; Allium and X-ray microscopy

\section{Introduction}

As the threat of climate change rages on, the frequency of dehydration stress and the risk posed by fungal pathogens is on the rise. These challenges are further complicated by the sessile nature of plants, which must survive a range of a combination of abiotic and biotic stresses. The cell wall serves as a barrier against stress, in addition to providing critical mechanical and structural support to the plant [1,2]. The ability of the cell wall to function in a range of mechanisms is dependent on the various components of the primary cell wall, including cellulose, hemicellulose, proteins and pectin [3]. Except for grasses, pectin is one of the most predominant components, comprising 30 to $50 \%$ of the cell wall dry matter [3]. Therefore, the composition of pectin is integral to the growth, morphology and development of the cell well, as well as in its ability to defend the plant against stress [4]. 
Pectin, the most structurally complex polysaccharide found in nature, is a five-member family currently considered to include: (1) Homogalacturonan (HG); (2) Rhamnogalacturonan I (RG-I); (3) Rhamnogalacturonan II (RG-II); (4) Xylogalacturonan (XGA); and (5) Apiogalacturonan (AP) [4]. HG and RG-II account for approximately $65 \%$ and $10 \%$ of all pectin, respectively, and have the unique ability to form more complex structures through cross-linkages to other elements [4-6].

Under the prevailing view, calcium ions form cross-linkages to carboxylate ions in demethylesterified galacturonic acid residues of HG [5,7]. The demethylesterifcation of HG occurs by way of pectin methylesterases (PMEs) [7] and pectin methylesterase inhibitors (PMEIs) provide negative feedback to PMEs [7]. In comparison, RG-II forms cross-linkages with boric acid, creating RG-II dimers [8]. These borate-diol ester cross link a boron atom and the apiosyl residue of side chain A in RG-II [8]. The formation of these cross-linkages maintains structural stability by reducing porosity while enhancing tensile strength and bound water in the cell wall fraction [9-16]. Increasing the quantity of bound water within the cell wall maintains tissue hydration and turgor pressure in addition to increasing cell wall rigidity [14]. Debra Mohnen's group recently proposed a new model for pectin structure consisting of a family of glycans (homoglycans, heteroglycans and proteoglycans) [17] and therefore, aspects of the current cell wall models may need to be reconsidered as more information emerges.

HG and RG-II have also been implicated as key forms of pectin in mitigating the resistance to desiccation and drought stress in several species, such as green algae and wheat cultivars [18-23]. This is likely the result of pectin forming hydrated gels, which in turn may limit damage during dehydration stress [19]. The degree of pectin methylation has also been linked to their ability to hold water, with reduced methylation increasing the water holding capacity of pectin [12]. Willats et al. (2001) also found the addition of calcium to pectin gels influences the water holding capacity, presumably as a result of "egg-box" structures [12]

The analysis of the MUR1 gene has further implicated RG-II dimers as an important aspect of the tolerance to freezing stress, tied to dehydration stress resistance [24]. Despite these findings, there is a need for greater research regarding the role calcium and boron on the structure-function of the cell wall in relation to dehydration stress resistance.

Previous research has additionally highlighted the important role that pectin plays in allowing the cell wall to function as a barrier to Botrytis cinerea, a necrotrophic pathogen, and Colletotrichum higginsianum, a hemibiotrophic pathogen. Lionetti et al. (2007) observed increased resistance to $B$. cinerea in Arabidopsis as a result of the over-expression of PMEI1 and PMEI2 [25]. Other PMEIs have also been reported to increase plant resistance to $B$. cinerea [26]. Interestingly, PMEs play a beneficial role in the immunity against $B$. cinerea, despite the opposing nature of PMEIs and PME [27]. More generally, pectin has been identified as a main target during a B. cinerea infection [28]. Petrasch et al. (2019) reported that, during the process of a $B$. cinerea infection, the pathogen heavily degrades the cell wall and, in particular, pectin [28].

PMEIs also play a role in the immune response during a C. higginsianum infection [29]; however, research within this area is limited. A study conducted by Engelsdorf et al. (2017) found Arabidopsis pmei6-2 mutants had reduced susceptibility to C. higginsianum. Reduced susceptibility may be indicative of a connection between the establishment of a $C$. higginsianum infection and pectin content [29]. Nonetheless, further exploration into the role of PMEIs and C. higginsianum is required.

Boron application has also been shown to play a positive role in $B$. cinerea infections in a variety of species [30,31]. Qin et al. (2010) found boron application reduced the germination of $B$. cinerea spores, reduced germ tube elongation and mycelial spread in table grapes [30]. When paired with boron, calcium increased resistance to $B$. cinerea in strawberry plants [31]. In addition, while there is no apparent research on the impact of boron on C. higginsianum, borate was found to inhibit the germination of Colletotrichum gleosporioides spores in mangos [32,33]. 
Allium fistulosum and Allium cepa were selected based on their contrasting freezinginduced dehydration stress tolerance. A. fistulosum is extremely tolerant to freezing stress, withstanding temperatures as low as $-40^{\circ} \mathrm{C}$, while $A$. cepa lacks this ability $[34,35]$. Both species have easy to peel epidermal cell layers with a large cell size, making them an ideal species for this investigation. Arabidopsis was selected based on the wide range of genotypic mutant lines available and its close genetic relationship to Brassica rapa.

Since plants are often exposed to multiple stresses in the field, this study aims to gain a further understanding into the influence of calcium, boron and PMEI on pectin cross-linkages, and in turn, on the ability for the cell wall to act as a barrier against both water loss and fungal pathogens. We hypothesized the application of calcium and/or boron results in cell wall structural changes and increased resistance to both abiotic and biotic stress in Allium species and Arabidopsis thaliana.

\section{Method and Materials}

\subsection{Plant Material and Growth Conditions}

A. fistulosum seeds and Yellow Sweet Spanish A. cepa seeds (Early's Farm \& Garden Center, Saskatoon, SK, Canada) were grown in the Agriculture Greenhouses, University of Saskatchewan (Saskatoon, SK, Canada) in 6" pots containing Sunshine Mix No. 4 (Sungro Horticulture Canada Ltd. Seba Beach, AB, Canada) at approximately $25 / 22{ }^{\circ} \mathrm{C}$ (day/night) under natural light supplemented with high pressure sodium lights $(17 \mathrm{~h}$ photoperiod, average $600 \mu \mathrm{mol} \mathrm{m}^{-2} \mathrm{~s}^{-1}$ ). Watering (City of Saskatoon, SK, Canada, water) was applied every second day during the spring/summer months and every third day during the fall and winter months with $200 \mathrm{~mL}$ of 20-20-20 (NPK) fertilizer $\left(150 \mathrm{~g} \mathrm{~L}^{-1}\right.$ ) (Plant Prod, Brampton, ON, Canada) weekly during the spring/summer months and twice weekly during the fall/winter months. The experiment was arranged in a randomized complete block design across the bench.

In addition, five $A$. thaliana genotypes were analyzed: three boron transporter mutants (nip5;1-1 (SALK_122287C), nip6;1-2 (SALK_046323C) and bor1-3 (SALK_037312)), a pectin methylesterase inhibitor over-expression mutant (p35S::PMEI5) and a wild-type (Col-0) line, respectively [36-39]. The three boron mutants were obtained from the Arabidopsis Biological Resource Centre (ABRC) (Columbus, OH, USA). The transgenic line overexpressing PMEI5 driven by the Cauliflower mosaic virus (CaMV) $35 \mathrm{~S}$ promoter was provided courtesy of Kerstin Müller [39]. Lines were genotyped according to Edwards et al. (1991), with some modifications [40,41]. Gene specific primers were ordered from Integrated DNA Technologies (Coralville, IA, USA) (Table S1).

Arabidopsis plants were grown in the Agriculture phytotron (Conviron, Winnipeg, $\mathrm{MB}$, Canada) under $20{ }^{\circ} \mathrm{C}$ constant temperature, $50 \% \mathrm{RH}, 16 \mathrm{~h}$ photoperiod, with an irradiance of $150 \pm 10 \mathrm{~m}^{-2} \mathrm{~s}^{-1}$, and watered every second day (City of Saskatoon, SK, Canada). Two g/L fertilizer (20-20-20 NPK) was applied weekly.

\subsection{Forms of Calcium and Boron Application}

Calcium treatments of $100 \mathrm{~mL}$ of a $0.05 \mathrm{M} \mathrm{CaCl}_{2}$ (Fisher Scientific, Watham, MA, USA) were applied every second day for four weeks as a soil drench. For pectin solutions prepared with calcium or boron, $0.05 \mathrm{M}$ of $\mathrm{CaCl}_{2}$ or $\mathrm{H}_{3} \mathrm{BO}_{3}$ were added directly during the preparation of the pectin solution to ensure homogeneity.

\subsection{Rheology}

Two types of pectin were examined, TIC Pretested Pectin HM (69-75\% methylation) [42] slow set (standardized with dextrose) (TIC Gums, White Marsh, MA, USA) and GENU BETA pectin (55\% methylation) [43] (standardized with EU non-GM beet sucrose) (CP Kelco Atlanta, GA, USA). The HM pectin is derived from citrus pectin and as a result has a high HG content and a lower RG content, making it similar to the pectin found within the cell wall of Allium spp. [44,45]. GENU BETA pectin is produced from sugar beets, and as such it has a higher RG-II content ( $\sim 5 \%$ compared to $0.6 \%)$, making it more like the 
pectin found within Arabidopsis. Therefore, HG pectin was utilized as a proxy for Allium, while GENU BETA pectin was selected as a proxy for Arabidopsis.

Pectin viscosity was measured using the AR G2 rheometer (TA Instruments, New Castle, DE, USA) with the $40 \mathrm{~mm}$ smooth acrylic geometry. Measurements were taken at $20^{\circ} \mathrm{C}, 12{ }^{\circ} \mathrm{C}$ and $4{ }^{\circ} \mathrm{C}$. Viscosity was also measured throughout the temperature ramp. Prior to the first set of measurements at $20{ }^{\circ} \mathrm{C}$, the sample was conditioned to $20^{\circ} \mathrm{C}$ with a soak time of $120.0 \mathrm{~s}^{-1}$ and a duration of $60.0 \mathrm{~s}^{-1}$. Viscosity measurements were then taken for $300.0 \mathrm{~s}^{-1}$ with a shear rate of $0.11 \mathrm{~s}^{-1}$. The sampling rate for the measurements taken was $10 \mathrm{~s}^{-1} / \mathrm{pt}$. The temperature was then decreased to $12{ }^{\circ} \mathrm{C}$ at a rate of $5.0^{\circ} \mathrm{C} / \mathrm{min}$, with the shear rate remaining constant at $0.11 \mathrm{~s}^{-1}$. The sample was then conditioned with the same soak time and duration as stated above. Viscosity measurements were also conducted under the same conditions previously outlined. The temperature was decreased to $4{ }^{\circ} \mathrm{C}$ and measurements of viscosity were performed as previously described above. The experiment was repeated three independent times with four replicates of each treatment group per trial $(n=12)$.

\subsection{Texture Analysis}

The force required to shear $A$. fistulosum sheaths was evaluated using the 10-blade Allo-Kramer shearing compression cell, attached to the TMS-Pro Texture Press (Food Technology Corp., Sterling, VA, USA) in the Shand lab at the University of Saskatchewan. Calcium-treated plants received $100 \mathrm{~mL}$ soil drench of a $0.05 \mathrm{M} \mathrm{CaCl}_{2}$ solution every second day for four weeks. Each measurement was performed using three $4 \mathrm{~cm}$ sections of $A$. fistulosum sheaths, from the youngest leaf with the most developed sheath. The ligule and the epidermal cell layer were left intact. The full-scale load was $1000 \mathrm{~N}$, the crosshead speed was $500 \mathrm{~mm} \mathrm{~min}^{-1}$. The shear force (in Newtons) required to shear $1 \mathrm{~g}$ of fresh sample was calculated using Equation (1) [46]. The shear force was measured in $\mathrm{N} \mathrm{g}^{-1}$ [46]. The experiment was repeated three independent times, with four replicates per trial $(n=12)$.

$$
\text { Force Required to Shear Allium Sheaths }=\frac{\text { peak shear force }(\mathrm{N})}{\text { weight of sheaths }(\mathrm{g})}
$$

Equation (1). Force required to shear Allium fistulosum sheaths in $\mathrm{N} \mathrm{g}^{-1}$.

\subsection{Water Loss in Pure Pectin Standards}

TIC Pretested Pectin HM (69-75\% methylation) slow set (standardized with dextrose) was used as a model for pectin within Allium and GENU BETA pectin (55\% methylation) (standardized with EU non-GM beet sucrose) was a model for Arabidopsis pectin. Treatments consisted of pectin solutions at concentrations of $4 \%$ and $8 \%$, with and without $0.05 \mathrm{M}$ of $\mathrm{CaCl}_{2}$ or $0.05 \mathrm{M}$ of $\mathrm{H}_{3} \mathrm{BO}_{3}$. Overall, 12 different pectin solutions were examined with 4 replications per pectin solution treatment, and the experiment was repeated 3 times.

Gravimetric water loss on an analytical balance was recorded at hourly intervals over $0-6 \mathrm{~h}$ in the various pectin solutions. This timeline was selected following preliminary experiments. Approximately $1 \mathrm{~g}$ of each of the pectin solutions was evenly pipetted into Petri dishes from the center point. Throughout the course of the dehydration experiment, the lids were kept off the Petri dishes to allow for evaporation. The temperature remained constant at $23{ }^{\circ} \mathrm{C}$, with a relative humidity of $\sim 22 \%$. The percentage water loss was measured as per Equation (2).

$$
\text { Percentage Water Loss }=\left(1-\left(\frac{T 0 \text { weight }}{T(x) \text { weight }}\right) \times 100\right)
$$

Equation (2). Percentage water loss in pure pectin standards. Variable " $T$ " is equal to the mass of the plant tissue at a specified time point. 


\subsection{Allium Dehydration Stress Tolerance}

Dehydration tolerance was measured by first analyzing the percentage water loss over 16-18 h using $4 \mathrm{~cm}$ sections of A. fistulosum and A. cepa sheaths obtained from the youngest leaf with the most developed sheath. Both ends of the sheath were sealed with Vaseline ${ }^{\circledR}$ and weighed to obtain a T0 weight. The sheaths were then dehydrated under dark conditions at $23{ }^{\circ} \mathrm{C}$ and $\sim 33 \% \mathrm{RH}$. Weights were recorded at $16 \mathrm{~h}$ and $18 \mathrm{~h}$. Following dehydration, the sheaths were wrapped in moist Kim Wipes and placed in $50 \mathrm{~mL}$ Falcon tubes with the lid for $24 \mathrm{~h}$. The percentage water loss was measured and calculated (Equation (2)).

Following dehydration, viability was assessed based on the presence/absence of protoplasmic streaming and staining using fluorescein diacetate (FDA). Epidermal cell layers were peeled from the sheath prior to viability analysis. Protoplasmic streaming was observed using a digital LEICA DM4 B microscope (Wetzlar, Germany) at $40 \times$ with a LEICA DFC7000 T camera (Wetzlar, Germany). Protoplasmic streaming was quantified as a percentage of viability across the epidermal cell layer (Equation (3)). The same microscope was used to visualize epidermal cell layers at $40 \times$ following FDA staining.

$$
\text { Percent Cell Viability }=\frac{\text { number of cells with protoplasmic streaming }}{\text { total number of cells }}
$$

Equation (3). Percent cell viability based on protoplasmic streaming. Total cell count was measured by counting the number of cells within the frame at the $40 \times$ objective.

\subsection{Arabidopsis Dehydration Stress Tolerance}

Tolerance to dehydration stress was assessed by measuring percentage water loss every hour over $10 \mathrm{~h}$ in the total above ground biomass of the various two-week-old genotypes. An initial weight was recorded at $0 \mathrm{~h}$ and then every $2 \mathrm{~h}$ until $10 \mathrm{~h}$. The percentage water loss was measured and calculated (Equation (2)). The samples were kept under dark conditions at $23{ }^{\circ} \mathrm{C}$ and $\sim 33 \% \mathrm{RH}$. Prior to dehydration, the severed end of the shoot was sealed using Vaseline ${ }^{\circledR}$. Following dehydration, plants were rehydrated in $2 \mathrm{~mL}$ sepia toned bottles with $100 \mu \mathrm{L}$ of $\mathrm{dH}_{2} \mathrm{O}$.

Viability following dehydration was assessed using electrical conductivity (Twin Compact Meter, Horiba, Japan) by first adding $1000 \mu \mathrm{L}$ of $\mathrm{dH}_{2} \mathrm{O}$ to the bottles $\sim 24 \mathrm{~h}$ following rehydration and then placing the bottles on the shaker for $\sim 19 \mathrm{~h}$ at $23{ }^{\circ} \mathrm{C}$. A second total electrical conductivity measurement was then taken after placement in a $100{ }^{\circ} \mathrm{C}$ dry bath for $10 \mathrm{~min}$ and then vortexed. Percentage electrolyte leakage $(\mu \mathrm{S} / \mathrm{cm})$ was measured and calculated (Equation (4)) [47].

$$
\text { Perecent Electrolyte Leakage }=\frac{\left(\left(\frac{\text { Pre-Boil Conductivity Value }}{\text { Post-Boil Conductivity Value }}\right) \times 100\right)}{T 0 \text { weight }}
$$

Equation (4). Percent electrolyte leakage in Arabidopsis thaliana above ground biomass following dehydration, where $T 0$ was the time at $0 \mathrm{~h}$.

The experiment was conducted under dark conditions to minimize the amount of water lost through open stomata. Stomatal closure was confirmed using the Suzuki Universal Micro-Printing (SUMP) method [48]. SUMP discs and SUMP liquid were used to take imprints of stomata, while a digital LEICA DM4 B microscope (Wetzlar, Germany) at $40 \times$ with a LEICA DFC7000 T camera (Wetzlar, Germany) attached assessed the imprints.

\subsection{Calcium Localization}

Calcium was spatially localized within single epidermal cell layers obtained from A. fistulosum using X-ray microscopy. Plants were grown and treated with calcium chloride as outlined above. The peeled epidermal layers were laid flat on Kapton tape and were used for data collection at the Advanced Photon Source (APS) beamline (20-ID: 
Sector 20-Insertion Device Beamline) (Lemont, IL, USA). Characteristics of the X-ray beam: incident energy-10 keV; sample scanning area-160 $\mu \mathrm{m} \times 160 \mu \mathrm{m}$; scanning step size $-1 \mu \mathrm{m}$; and dwell time- 10 milliseconds per pixel. A total of 10 vertical scan maps were collected at a depth of every $2 \mu \mathrm{m}$ into the sample [49].

Two-dimensional images were processed using PyMCA to fit the normalized average spectra of all points on the map and to generate the calcium distribution map (Version 5.3.1) [50]. OriginPro (Northhampton, MA, USA) was then used to plot the calcium map and to increase image quality by eliminating the saturated pixels. False color maps were produced using rainbow color scheme in which the blue-to-red color gradient shows low-to-high relative calcium concentrations.

The completed images were then analyzed using the "histogram" feature on ImageJ (Version 1.53a) to gain a greater understanding into differences in RGB pixels between control and calcium-treated epidermal cell layers.

\subsection{Colletotrichum higginsianum Infection}

C. higginsianum Sacc culture, isolate IMI349061, originating from Brassica rapa (CABI Bioscience), was prepared as outlined in Liu et al. (2010) and Liu et al. (2007) [51,52]. Spores were suspended in $\mathrm{ddH}_{2} \mathrm{O}$, with a final concentration of $10^{6}$ spores $/ \mathrm{mL}$. Plants were inoculated by applying multiple single $1 \mu \mathrm{L}$ droplets of inoculant to the oldest leaf, avoiding the mid-vein.

Throughout the course of infection, leaves were maintained on moist filter paper in Petri dishes kept under a 16-8 h/light-dark period $\left(150 \pm 10 \mu \mathrm{mol} \mathrm{m}^{-2} \mathrm{~s}^{-1}\right)$ during the first 2 and last 2 days of the period of infection, at the third day the plates were transferred to complete darkness. Complete darkness was used to promote germination of the appressorium, while the leaves were transferred back to a day/night light cycle on days $4-5$ to prevent chlorosis at approximately $20^{\circ} \mathrm{C}$ throughout.

Infection was then evaluated every $24 \mathrm{~h}$ based on the percent total leaf area infected (Equation (5)). The lesion area was measured using Image (Version 1.53a).

$$
\text { Percent leaf area infected }=\left(\frac{\text { Lesion area }\left(\mathrm{cm}^{2}\right) \text { at } T(x)}{\text { Total leaf area }\left(\mathrm{cm}^{2}\right) \text { at } T(x)}\right) \times 100
$$

Equation (5). Percent leaf area infected by Botrytis cinerea and Colletotrichum higginsianum, where $T(x)$ was the time point of interest.

\subsection{Botrytis cinerea Infection}

B. cinerea grown on potato dextrose agar (PDA) for 7 days at $22{ }^{\circ} \mathrm{C}$ was used to inoculate four-week-old $A$. thaliana leaves [53]. The leaves were inoculated using a solution containing $B$. cinerea mycelium suspended in $\mathrm{ddH}_{2} \mathrm{O}$, with a final concentration of $10^{6}$ spores $/ \mathrm{mL}$. Three $1 \mu \mathrm{L}$ droplets of the mycelium containing solution were applied to one half of the leaf, while three $1 \mu \mathrm{L}$ droplets of water were applied to the other half. Caution was taken to avoid the leaf mid-vein. Throughout the course of infection $(120 \mathrm{~h})$, the leaves were maintained on moist filter paper within sealed Petri dishes and kept the dark at $23{ }^{\circ} \mathrm{C}$ throughout the course of infection.

The infection was evaluated based on the percent total leaf area infected (Equation (5)).

\subsection{Statistical Analysis}

Analyses related to shear force, water loss, protoplasmic streaming, electrolyte leakage, and fungal pathogens were performed using ANOVA tests, with Tukey's tests as a method of post hoc analysis $(p<0.05)$. Two-tailed two-sample $t$-tests $(p<0.05)$ analyzed calcium localization according to differences in RGB pigmentation and differences in the intensity of green pixels following FDA staining.

Rheological results were analyzed using generalized additive models (GAMs). Models were initially fit based on each fixed explanatory variable separately, prior to fitting models 
at all fixed explanatory variables together. Data were log-transformed. GAMs were generated using the gam function from the "mgcv" package [54,55]. The Akaike information criterion (AIC) score was used when building models to select for the optimum model. Function gam.check was used for model checking. GAMs were analyzed using ANOVA, with F-tests. Figures of each GAM were individually created for each of the pectin solutions using function "plot.gam", in addition to the packages "mgcViz" and "rgl" [56,57]. The package "devtools" was used to download the color palette, and "inauguration_2021" was used for coloration figures [58].

All statistical analyses were performed with the RStudio statistical software (Version 1.2.5033). In addition to the previous packages mentioned, "ggplot" and "ggplot2" were also used [58].

\section{Results}

Pectin viscosity significantly $(p<0.05)$ increased under the application of boron alone in both HM pectin and GENU BETA sugar beet (GB) pectin (Figure S1, Table S2). Boron had a more pronounced impact on $8 \% \mathrm{HM}$ pectin viscosity at $5{ }^{\circ} \mathrm{C}$, increasing the viscosity of $\mathrm{HM}$ pectin to just over $6000 \mathrm{~Pa} .5^{\circ} \mathrm{C}$ compared to $8 \% \mathrm{~GB}$ pectin with boron, which had an average viscosity of less than 4000 Pa.s at $5{ }^{\circ} \mathrm{C}$ (Figure 1). Boron also had a more notable impact on $\mathrm{HM}$ pectin at $12{ }^{\circ} \mathrm{C}$, with the trend only changing at $20^{\circ} \mathrm{C}$, when boron increased GB pectin viscosity to levels greater than HM pectin viscosity (Figure 1). Interestingly, calcium application alone did not have a significant effect on pectin viscosity (Table S2). As outlined in Section 2.2, calcium and boron were added directly to the pectin solution. However, calcium did have a significant effect on pectin viscosity when its influence was considered in combination with increasing pectin concentration and temperature (Table S2). The effect of boron on pectin viscosity remained significant when its effect was considered in combination with increasing pectin concentration and temperature (Table S2).
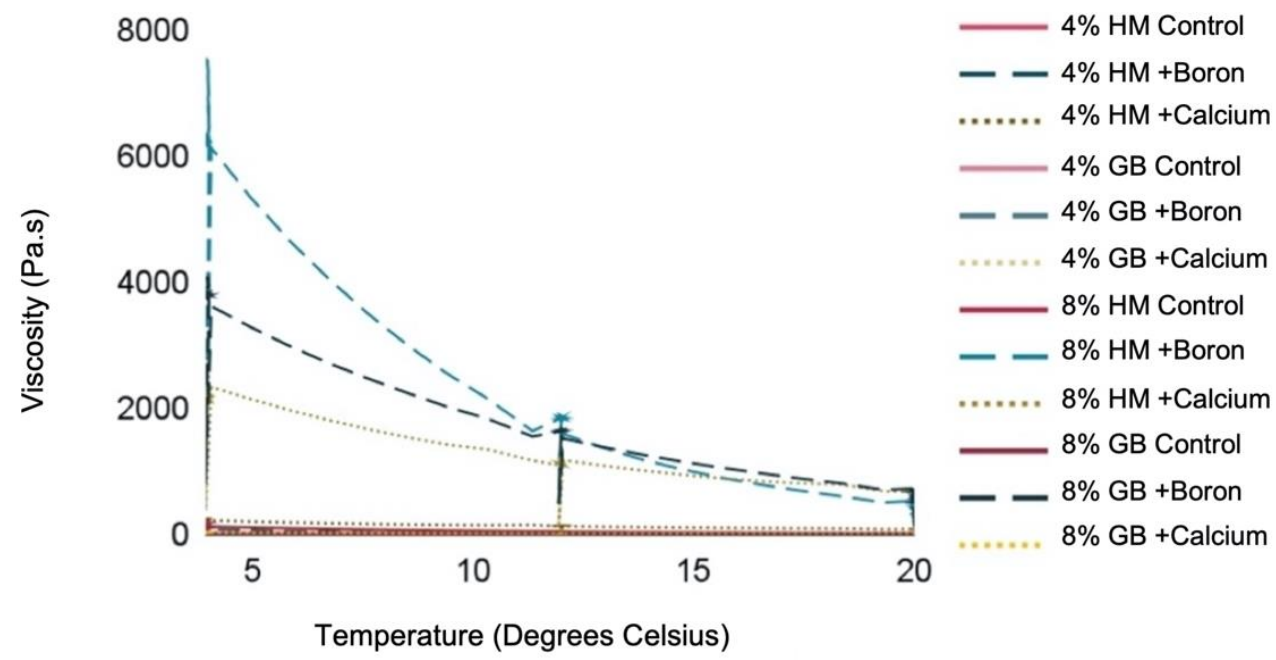

Figure 1. Change in viscosity (Pa.s) as temperature $\left({ }^{\circ} \mathrm{C}\right)$ increased. Viscosity was analyzed across two concentrations of pectin $(4 \%$ or $8 \%$ ), two types of pectin (high methylated citrus pectin or GENU BETA sugar beet pectin) and with either calcium $\left(0.05 \mathrm{M} \mathrm{CaCl}_{2}\right)$, boron $\left(0.05 \mathrm{M} \mathrm{H}_{3} \mathrm{BO}_{3}\right)$ or no additional element.

The analysis of the force required to shear $A$. fistulosum sheaths revealed the application of calcium (applied as a soil drench) resulted in a significantly $(p<0.05)$ higher Allo-Kramer shear force $\left(265.0 \mathrm{~N} \mathrm{~g}^{-1}\right)$, compared to $A$. fistulosum plants that had not received calcium (210.6 $\mathrm{N} \mathrm{g}^{-1}$ ) (Figure 2). This increase in shear force is representative of an increased toughness within the sheaths. Toughness is a mechanical property that describes the ability for a material to resist fracture $[59,60]$. The toughness of a material is influenced by both its strength and ductility $[59,60]$. 


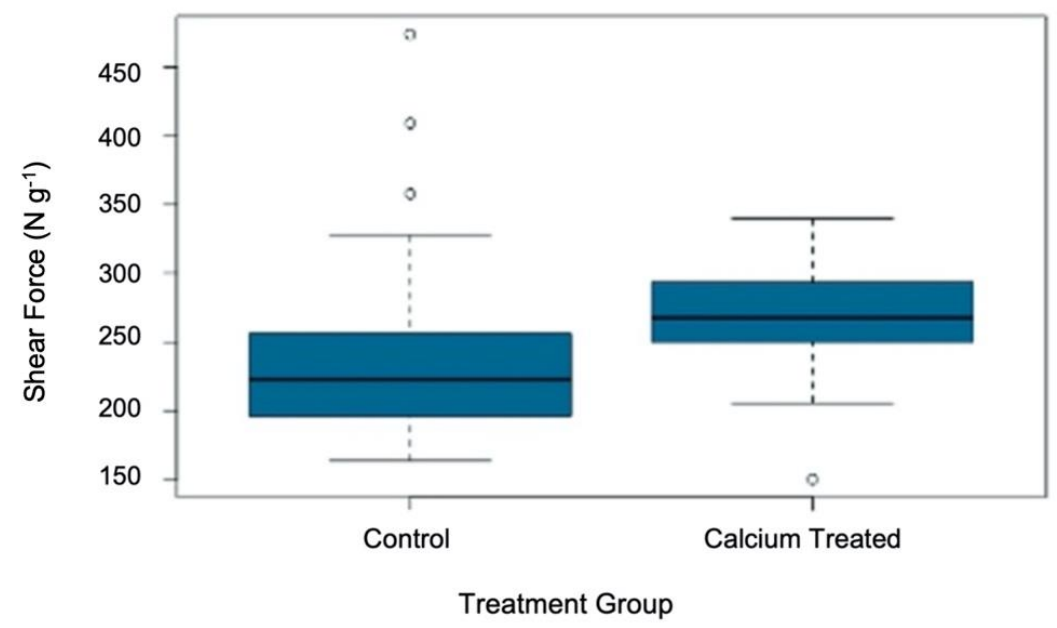

Figure 2. The effect of calcium application on the force $\left(\mathrm{N} \mathrm{g}^{-1}\right)$ required to shear through Allium fistulosum sheaths. Plants treated with calcium received $100 \mathrm{~mL}$ of a $0.05 \mathrm{M} \mathrm{CaCl}_{2}$ solution every second day. See Table S3 for statistical analysis.

Calcium was spatially localized within A. fistulosum epidermal cell walls (Figure 3). Xray microscopy imaging showed that the exogenous application of calcium to $A$. fistulosum increased the concentration of calcium within the cell layer, with the additional calcium primarily localizing to the apoplast (Figure 3). The spatial localization of calcium to the apoplast is evident in Figure 3B, where epidermal layer cell walls can be observed because of increased calcium concentrations in the apoplast (more intense lighter blue color). This calcium appears to be primarily distributed to the radial cell walls. These areas of interest are identified using white arrows. Small flecks of white, light blue and green are also visible across both Figure 3A,B. These, in addition to red flecks, which are more pronounced on Figure $3 \mathrm{~B}$, represent calcium contamination and are not related to structures within the cell layer.
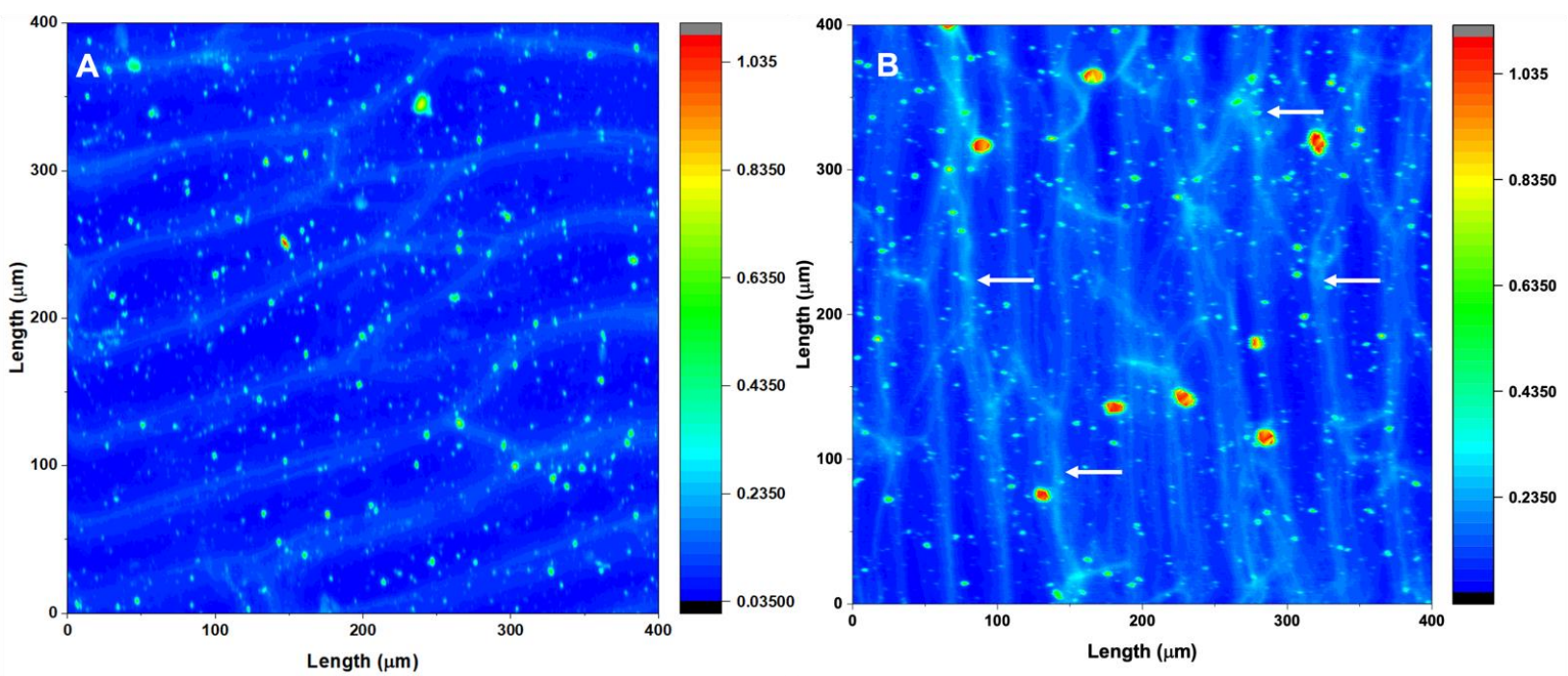

Figure 3. 2D Calcium map obtained using the 20-ID beamline at the Advanced Photon Source, Lemont, IL, and the X-ray microscopy technique. Calcium concentration is represented by color changes within the map, with darker blue indicating a lower concentration of calcium to red indicating a higher concentration of calcium. White arrows point to sample areas where calcium appears to localize to the apoplast. (A) Single Allium fistulosum epidermal cell layer obtained from a control plant without calcium treatment. (B) Single Allium fistulosum epidermal cell layer obtained from a plant treated with a soil drench of $100 \mathrm{~mL}$ of a $0.05 \mathrm{M} \mathrm{CaCl}_{2}$ every second day for four weeks. 
In addition to increasing the toughness of $A$. fistulosum sheaths, calcium application significantly $(p<0.05)$ reduced percentage water loss, as did increasing pectin concentrations (Figure 4B). An 8 percent high methylated citrus pectin with calcium (proxy for Allium) lost the least amount of water after $6 \mathrm{~h}$ (48.5\%), while $8 \%$ GENU BETA pectin with calcium (proxy for Arabidopsis) had a water loss of 58.3\% after $6 \mathrm{~h}$ (Figure $4 \mathrm{~A}$ ). However, the effect of calcium in mitigating dehydration stress in Allium species tissue was not significant $(p>0.05)$ (Table S4).
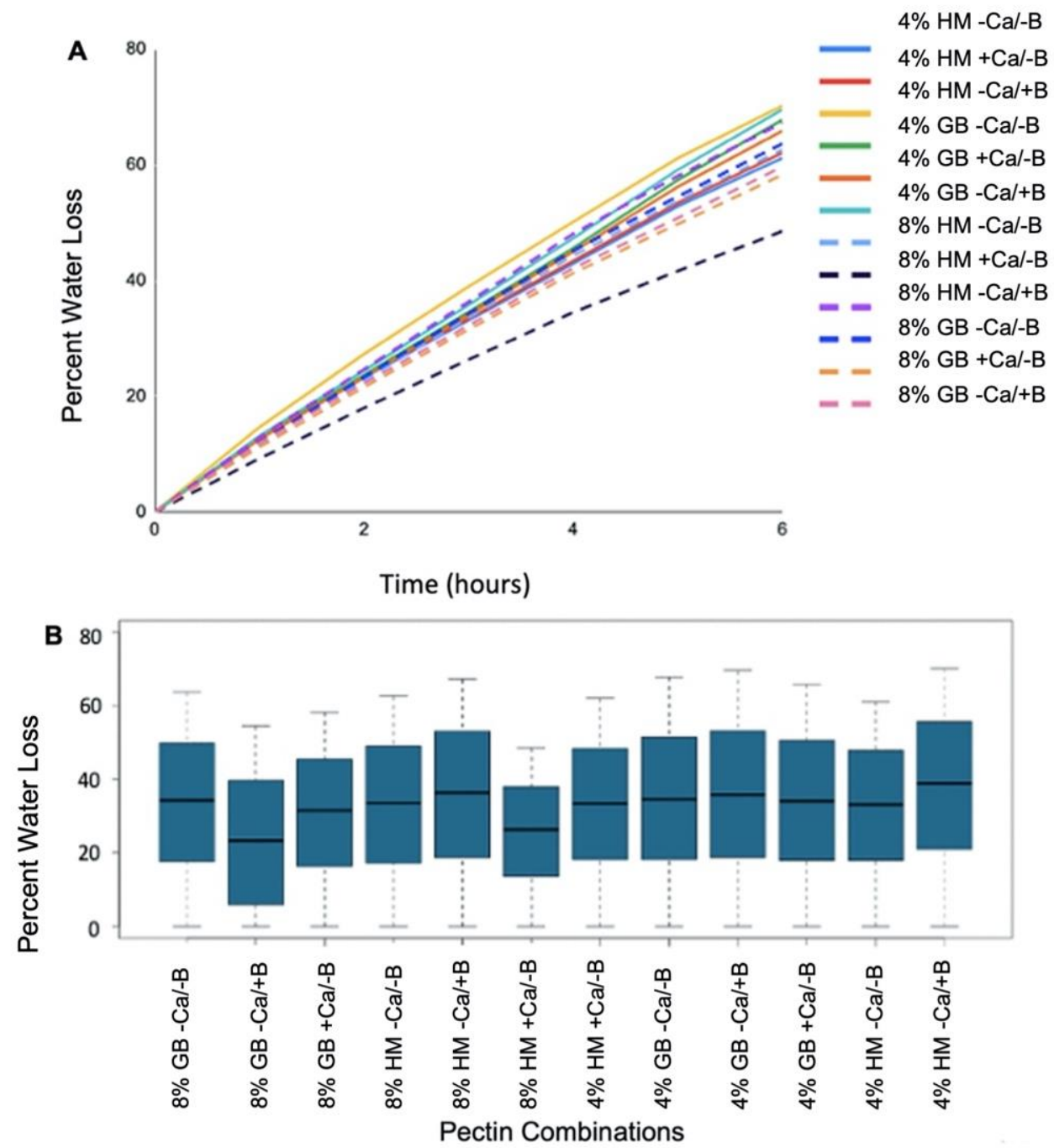

Figure 4. (A) Percent water loss over $6 \mathrm{~h}$ over a $6 \mathrm{~h}$ period for the 12 pectin solutions of interest. Amongst the 12 solutions, there are two concentrations ( $4 \%$ or $8 \%$ ), two pectin types (high methylated (HM) citrus pectin or GENU BETA (GB) (sugar beet) pectin), and the addition of calcium (Ca) (0.05 M $\left.\mathrm{CaCl}_{2}\right)$, boron (B) $\left(0.05 \mathrm{M} \mathrm{H}_{3} \mathrm{BO}_{3}\right)$ or no additional element. (B) Boxplot of average percent water loss over a $6 \mathrm{~h}$ period for the 12 pectin solutions of interest. Amongst the 12 solutions, there are two concentrations ( $4 \%$ or $8 \%$ ), two pectin types (high methylated (HM) citrus pectin or GENUA BETA (GB) (sugar beet) pectin), and the addition of calcium (Ca) (0.05 $\left.\mathrm{M} \mathrm{CaCl}_{2}\right)$, boron (B) $\left(0.05 \mathrm{M} \mathrm{H}_{3} \mathrm{BO}_{3}\right)$ or no additional element. See Tables S5 and S6 for statistical analysis.

The freezing-tolerant $A$. fistulosum was also significantly $(p<0.05)$ more resistant to dehydration stress compared to the freezing-sensitive $A$. cepa (Figure 5B). After $17 \mathrm{~h}, A$. fistulosum sheaths had a percentage water loss of $27.1 \%$, while sheaths obtained from $A$. cepa lost $33.1 \%$ water (Figure $5 \mathrm{~A}$ ). A. fistulosum continued to lose less water as the period of dehydration was extended from $16 \mathrm{~h}$ to $18 \mathrm{~h}$, retaining $5.2 \%$ more water compared to $A$. cepa $(28.1 \%$ compared to $33.3 \%$ ) (Figure $5 \mathrm{~A})$. 

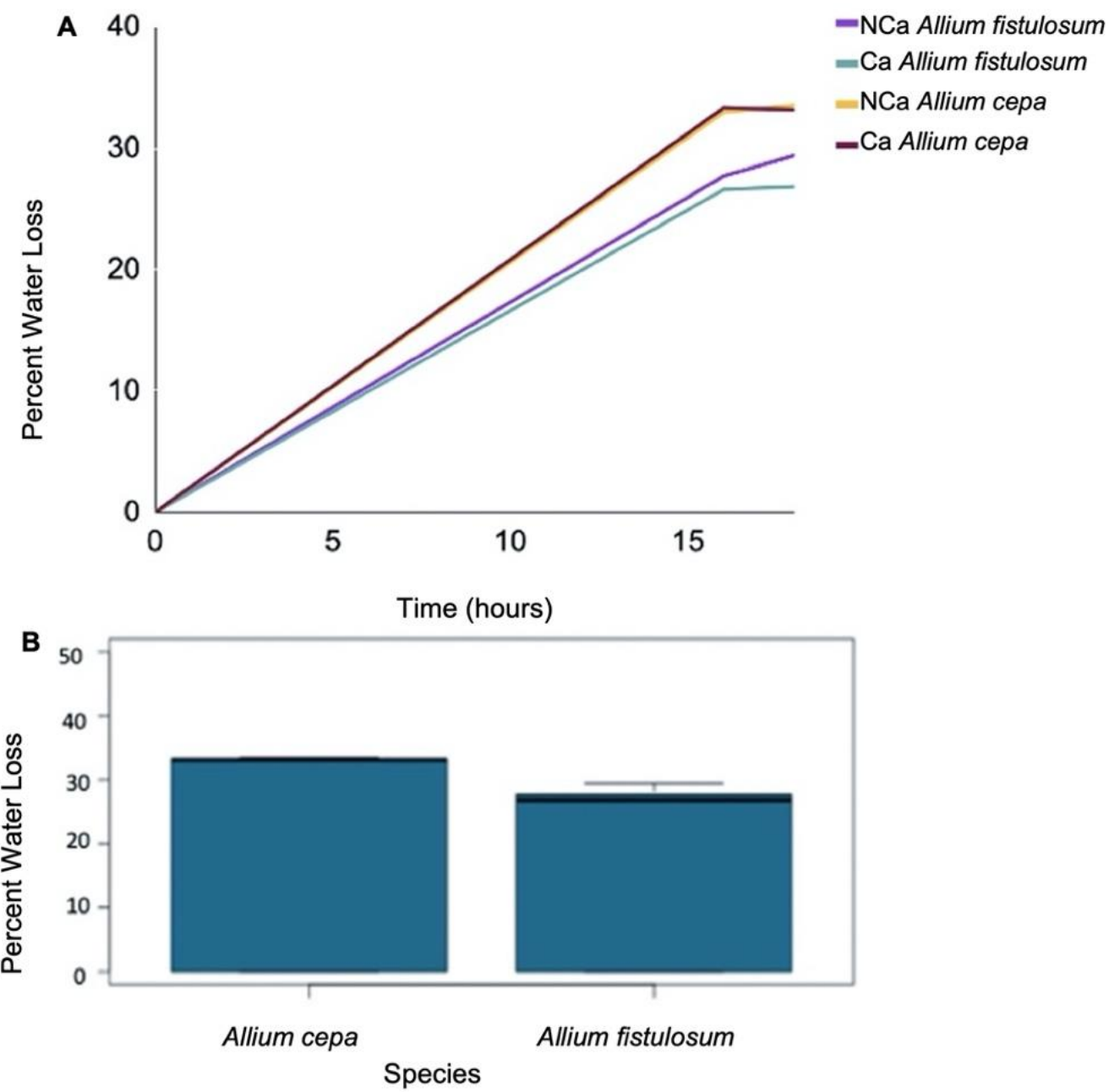

Figure 5. (A) Percent water loss over $16-18 \mathrm{~h}$ in Allium fistulosum and Allium cepa. Plants treated with calcium (CA) received $100 \mathrm{~mL}$ of a $0.05 \mathrm{M} \mathrm{CaCl}_{2}$ every second day for four weeks. Control plants (NCA) did not receive calcium. (B) Boxplot showing average percent water loss over 16-18 h in Allium fistulosum and Allium cepa sheaths. Each bar represents both control and calcium treated plants combined. See Table S4 for statistical analysis.

In addition, epidermal cell layers from dehydrated and subsequently rehydrated $A$. fistulosum sheaths had a significantly $(p<0.05)$ higher percentage viability based on protoplasmic streaming compared to A. cepa (Figure $6 \mathrm{~B}$ ). After $16 \mathrm{~h}$ of dehydration, cell layers obtained from $A$. fistulosum had a $57.6 \%$ viability compared to $7.1 \%$ in $A$. cepa (Figure 6A). The trend of increased viability in A. fistulosum continued as the length of dehydration was extended. After $18 \mathrm{~h}$, A. fistulosum epidermal cell layers had $39.2 \%$ viability while those obtained from $A$. cepa had a percent viability of $2.5 \%$ (Figure $6 \mathrm{~A}$ ).

In addition, there was a higher level of FDA-based "greenness" within calcium treated cell layers, indicating an increased level of viability (Figures S2 and S3). Generally, cell layers obtained from $A$. fistulosum also had a significantly $(p<0.05)$ increased level of greenness compared to those obtained from $A$. серa, indicating greater viability following dehydration stress (Table S8). In addition, differences amongst other relationships were also found to be statistically significant $(p<0.05)$ (Table S8).

Boron also significantly $(p<0.05)$ reduced water loss in pure pectin solutions (Figure $4 \mathrm{~B}$ ). After 6 h, 8\% GENU BETA pectin with boron (proxy for Arabidopsis) had a 59.7\% water loss compared to $63.7 \%$ for the GENU BETA pectin control (Figure 4A). While similar dehydration stress tolerance trends were observed in Arabidopsis boron transporter mutants, the differences were non-significant $(p>0.05)$ (Figure 7B). Moreover, the over-expression of PMEI5 did not significantly influence dehydration stress resistance $(p>0.05)$ (Figure 7B). 


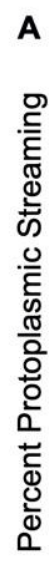

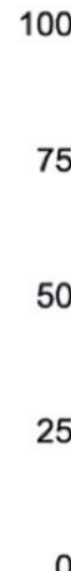

75
50
25
0

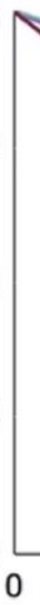

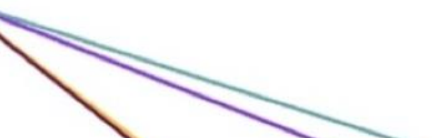

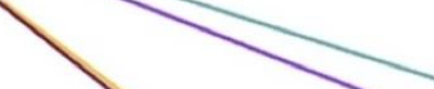

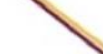
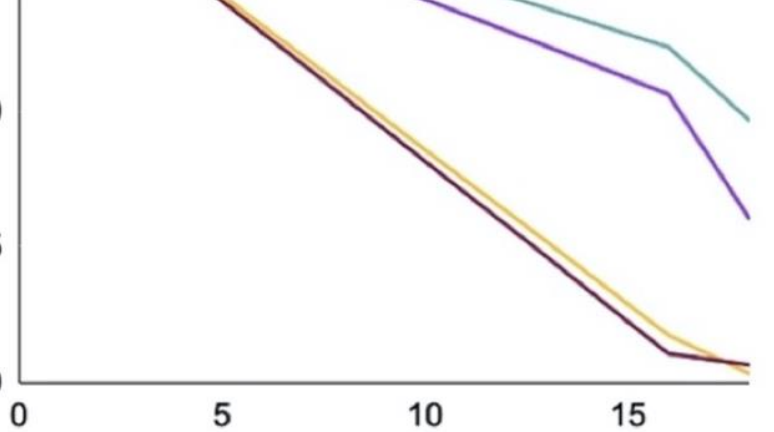

B

Time (hours)
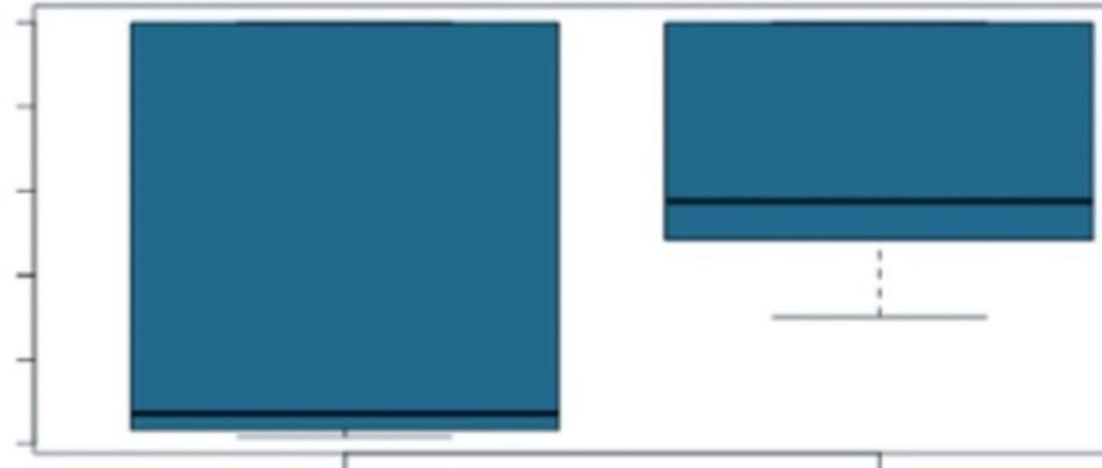

Allium cepa

Allium fistulosum

Species

Figure 6. (A) Percent protoplasmic streaming in Allium fistulosum and Allium cepa epidermal cell layers following dehydration over 16-18 h. Plants treated with calcium (CA) received $100 \mathrm{~mL}$ of a $0.05 \mathrm{M} \mathrm{CaCl}_{2}$ every second day for four weeks. Control plants (NCA) did not receive calcium. (B) Boxplot showing percent protoplasmic streaming for Allium fistulosum and Allium cepa, following a 16-18 h dehydration period. Each bar represents both control and calcium treated plants combined. See Table S7 for statistical analysis.

However, mutations in boron transporters and the over-expression of PMEI5 were found to influence the rate of infection for both fungal pathogens (Figure 7). The analysis of the rate of $B$. cinerea infection amongst the genotypes of interest found bor 1 to be the most susceptible to the pathogen, consistently having the greatest percent area of infection from $1 \mathrm{dpi}$ (days post-inoculation) (Figure 7). In general, the percentage of leaf area infected in the bor 1 leaves was significantly $(p<0.05)$ greater compared to all the other genotypes of interest (Figure 7B). At $5 \mathrm{dpi}, 100 \%$ of the bor 1 leaf tissue was covered in a B. cinerea lesion (Figure 7A). By comparison, nip6;1 had $60.7 \%$ of its leaf area infected, leaves obtained from nip5; 1 were $61.4 \%$ covered in a B. cinerea lesion, while $p 35 S:: P M E I 5$ leaves were $68.4 \%$ infected (Figure 7A). Col-0 leaves were 71.4\% covered by the lesion (Figure 7A).

In general, over the entire course of the infection, bor1 was also significantly $(p<0.05)$ more susceptible to C. higginsianum compared to Col-0 (Figure 8B). At $5 \mathrm{dpi}$, over $60 \%$ of bor1 leaf tissue was covered in a lesion caused by $C$. higginsianum, while all other genotypes of interest had less than $40 \%$ of their leaf tissue covered by a lesion (Figure $8 \mathrm{~A}$ ). At $1 \mathrm{dpi}$, the percentage leaf area covered by lesions from C. higginsianum was over $30 \%$ larger compared to the other genotypes analyzed (Figure 8A). 


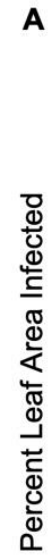

100

00

75

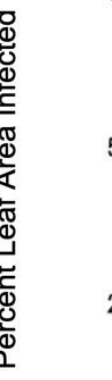

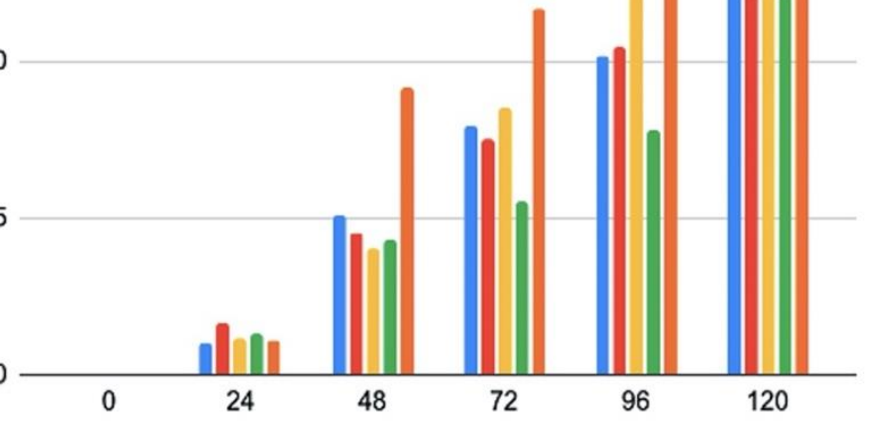

Time (hours)

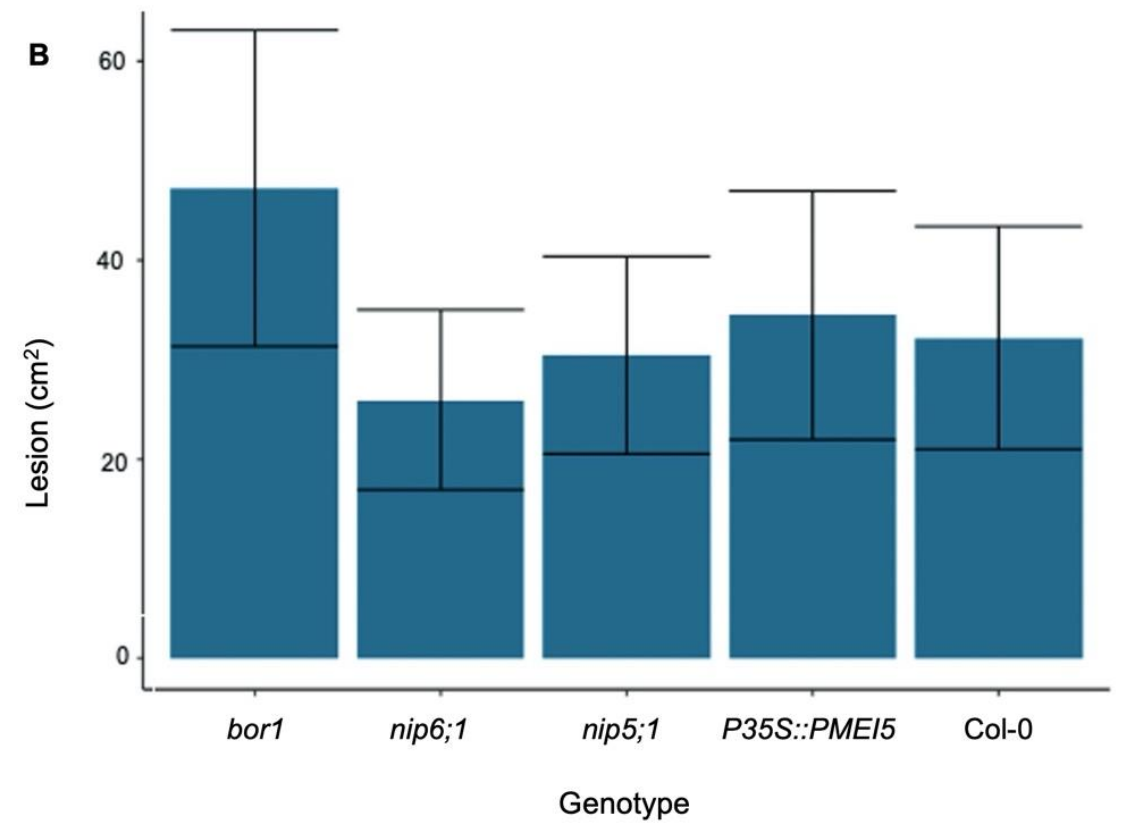

Col-0

nip5; 1

P35S::PMEI5

nip6;1

bor1

Figure 7. (A) Average lesion size on Arabidopsis thaliana leaves caused by Botrytis cinerea. Five genotypes were examined (bor1 (boron transporter mutant), nip5;1 (boron transporter mutant), nip6;1 (boron transporter mutant), p35S::PMEI5 (PMEI overexpression), and Col-0 (wild type)) over a 0-120 h period post-inoculation. (B) Boxplot showing average lesion size on Arabidopsis thaliana leaves caused by Botrytis cinerea. Five genotypes were examined (bor1 (boron transporter mutant), nip5;1 (boron transporter mutant), bor1 (boron transporter mutant), nip6;1 (boron transporter mutant), p35S::PMEI5 (PMEI mutant), and Col-0 (wild type)) over a 0-120 h period post-inoculation. Error bars represent standard error. See Tables S9 and S10 for statistical analyses. 


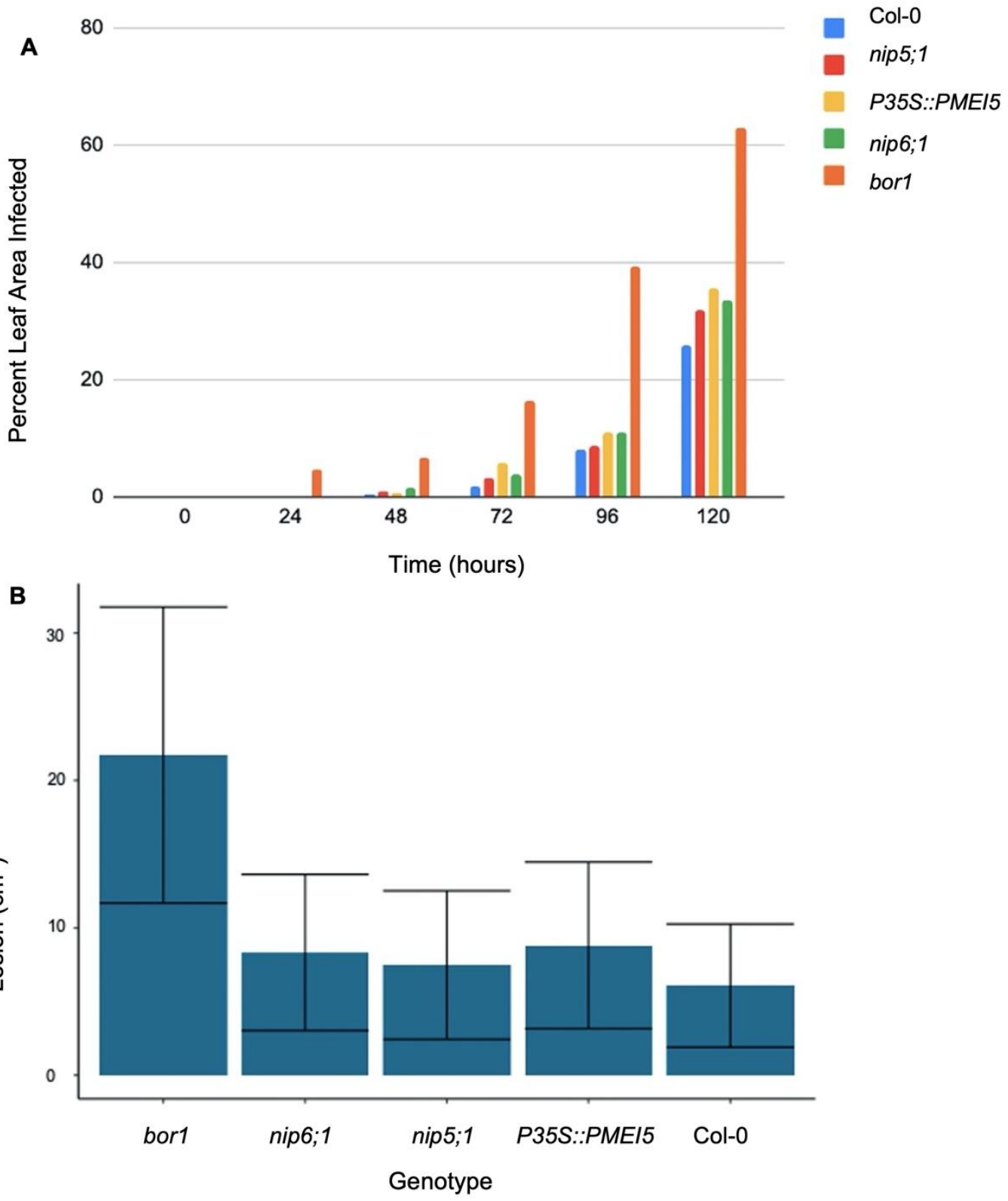

Figure 8. (A) Average lesion size on Arabidopsis thaliana leaves caused by Colletotrichum higginsianum. Five genotypes were examined (bor1 (boron transporter mutant), nip5; 1 (boron transporter mutant), bor1 (boron transporter mutant), nip6;1 (boron transporter mutant), p35S::PMEI5 (PMEI mutant), and Col-0 (wild type)) over a $0-120 \mathrm{~h}$ period post-inoculation. (B) Boxplot showing average lesion size on Arabidopsis thaliana leaves caused by Botrytis cinerea. Five genotypes were examined (bor 1 (boron transporter mutant), nip5;1 (boron transporter mutant), bor1 (boron transporter mutant), nip6;1 (boron transporter mutant), p35S::PMEI5 (PMEI mutant), and Col-0 (wild type)) over a 0-120 h period post-inoculation. Error bars represent standard error. See Tables S11 and S12 for statistical analyses.

\section{Discussion}

\subsection{Mechanical Changes and Calcium Localization}

The structural role that pectin plays in the cell wall is critical to a plant's ability to withstand stress [4]. Within the cell wall, pectin is far from the only critical component. However, what sets pectin apart from other components of the cell wall is the unique ability for HG and RG-II to form complex structures through cross-linkages to other elements $[5,7]$. Both the rheological results and those obtained from the analysis of shear force are suggestive that structural changes occurred because of calcium and boron application. Furthermore, 
the addition of these elements likely resulted in the formation of "egg-box" structures and RG-II dimers, as they are known to influence cell wall integrity, including rigidity and tensile strength $[6,7,61]$.

The notion that calcium-HG cross-links form within A. fistulosum epidermal cell walls because of calcium application is further supported by images obtained from the Advanced Photon Source (Lemont, IL, USA) using the 20-ID beamline, the X-ray microprobe technique and X-ray fluorescence. These images clearly show an accumulation of calcium around the cell walls of epidermal cells obtained from calcium treated A. fistulosum and are a key piece of the puzzle in the narrative of the formation of "egg-box" structures. Within plant cells, pectin is only found within the cell wall and is most highly concentrated in the middle lamella and the primary cell wall [4]. Thus, the localization of calcium to the cell wall/middle lamella region and the increased shear force suggest that the application of calcium to $A$. fistulosum results in the formation of calcium-HG cross-links. Our next step was to analyze how the likely formation of these structures, in addition to boron and PMEIs, would influence dehydration stress resistance.

\subsection{Dehydration Stress in Allium spp. and Pectin Proxy}

In addition to causing structural changes within plant tissue, the formation of calciumHG cross-linkages has also been tied to reduced cell wall permeability [12]. Thus, it was hypothesized the application of calcium would increase resistance to dehydration stress tolerance by reducing percentage water loss.

Even though calcium was found to significantly $(p<0.05)$ reduce percentage water loss in high methylated citrus pectin (proxy for Allium), the role calcium played on improving dehydration stress resistance in $A$. fistulosum and $A$. cepa was non-significant $(p>0.05)$ and is indicative of the complex nature of plants compared to pure systems. Nevertheless, previous studies have observed the efficacy of calcium application in enhancing drought stress tolerance/resistance in species such as Beta vulgaris, Nicotiana tabacum and wheat [62-64].

The discrepancy between these previous findings and those within this paper may be the result of a multitude of reasons, one of them being pore size. While the exact diameter of pores within the A. fistulosum epidermal cell layer is not known, previous research has found that, under cold acclimation, the diameter is reduced to less than $1.3 \mathrm{~nm}$; however, the diameter of a water molecule at $25^{\circ} \mathrm{C}$ is $\sim 0.27 \mathrm{~nm}(2.7 \AA)[65,66]$. Therefore, even if permeability was reduced as a result of calcium application, the pore size was still larger than that of a water molecule. The large volume of water within the sheaths of $A$. fistulosum and $A$. cepa may also mask the effect of the calcium treatment.

Calcium is a complex element within plant systems, playing a role in a wide range of functions, including acting as a signaling molecule [67]. In its role as a signaling molecule, calcium has also been found to influence tolerance and resistance to drought stress in a variety of species $[63,64,68]$. For example, Knight et al. (1997) observed changes in the concentration of free calcium within cytosol during drought stress treatment in Arabidopsis [68]. More generally, the three main calcium sensors (1) calcineurin B-like protein; (2) calmodulin, and calmodulin-like proteins; and (3) calcium-dependent protein kinases) transduce $\mathrm{Ca}^{2+}$ signals, in turn causing the phosphorylation of a downstream target [69-76]. This ultimately results in a response to drought stress.

While calcium was unable $(p>0.05)$ to improve the overall resistance to dehydration in either $A$. fistulosum or $A$. cepa, $A$. fistulosum was significantly $(p<0.05)$ more tolerant to dehydration stress. A. fistulosum has also been found to be more tolerant to freezinginduced dehydration as compared with $A$. cepa $[34,35]$. A. fistulosum tolerates temperatures around $-40{ }^{\circ} \mathrm{C}$, while $A$. cepa lacks the ability to cold acclimate beyond $-11^{\circ} \mathrm{C}[34,35]$. The connection between dehydration stress resistance and freezing stress tolerance is critical in the face of climate change. While initially drought stress and freezing stress may seem unrelated, both are tied to dehydration stress. During both drought stress and freezing stress, loss of turgor pressure can occur as the cell loses water [77-79]. As a result, cytorrhysis may occur beyond a tolerable limit. Oertli (1986) and Oertli et al. (1990) reported 
that the ability for the cell wall to resist cytorrhysis depends on the mechanical strength of the cell wall $[80,81]$. Therefore, the ability to resist dehydration stress and to tolerate freezing stress may be related to the mechanical strength of the wall within A. fistulosum. Pectin is known to play a large role in the strength and stability of the cell wall [4].

\subsection{Dehydration Stress in Arabidopsis and Pectin Proxy}

Similar to calcium and HG, boron and RG-II have the ability to form cross-linkages, which results in the formation of RG-II dimers [4-6]. Previous research by Panter et al. (2019) examining the MUR1 gene in Arabidopsis found that the formation of these RG-II dimers improves tolerance to freezing stress [24]. Since dehydration stress is associated with freezing stress, it is plausible that RG-II dimers positively influence the water holding capacity of pectin. Thus, the addition of boron to GENU BETA likely resulted in the formation of RG-II dimers since the $8 \%$ GENU BETA pectin with boron lost significantly $(p<0.05)$ less water after $6 \mathrm{~h}$ compared to $8 \%$ GENU BETA pectin without boron.

Boron was also found to influence dehydration stress resistance in Arabidopsis in the various boron-transporter mutants. While none of the observed changes in dehydration stress resistance were found to be significant $(p>0.05)$ amongst the three boron-transporter mutants explored, bor 1 lost the most water. Decreased resistance to dehydration stress in bor1 compared to nip5;1 and nip6;1 may be the result of differences in the roles of the boron transporters and further speaks to the importance of understanding the specific nature of the transporters.

Briefly, NIP5;1 and NIP6;1 are localized in the plasma membrane and are involved in borate transport [36,37]. NIP5;1 is also involved in arsenite transport [38]. In comparison, BOR1 is localized in the cytoplasm, endosome and vacuole in addition to the plasma membrane [38]. BOR1 is also involved in a wider range of functions, including detection of nutrients, ion homeostasis and transmembrane transport, as well as borate transport and response to boron-containing substances [38]. Therefore, a mutation in BOR1 may be more deleterious. However, there is a lack of additional research exploring NIP, BOR or other boron transporters in relation to dehydration stress resistance. Nonetheless, a range of species, including maize, wheat and tomatoes, had enhanced drought stress tolerance as a result of boron application $[22,23,82,83]$. This further implicates the importance of boron, and likely its structural role in the ability to retain water.

In addition to calcium and boron, PMEIs are another important aspect of pectin modifications and cell wall structure. PMEIs provide negative feedback on PMEs, in turn controlling the ability for "egg-box" structure formation in addition to altering the cell wall in a range of other structural ways [7]. The family of PMEIs within Arabidopsis is broad, and currently includes 71 putative genes [7,84,85]. Despite a lack of significance $(p>0.05)$, our results showed an over-expression of PMEI5 was beneficial in resistance to dehydration stress, by way of reducing percentage water loss and electrolyte leakage.

While seemingly counterintuitive, given that the over-expression of PMEI would reduce the formation of "egg-box" structures, research from An et al. (2008) supports our findings [86]. They found the over-expression of CaPMEI1, a PMEI from peppers, enhanced tolerance to drought stress [86]. This was attributable to an increased tolerance to oxidative stress, which was observed in the CaPMEI1-OX Arabidopsis line, which may in turn reduce the damage caused by stresses such as drought [86]. However, findings by An et al. (2008) and those observed in this study stand in direct contrast to findings by from Amsbury et al. (2016) and Yang et al. (2019), who found increased de-methylation of pectin enhanced drought stress tolerance [86-88]. This may be the result of differences amongst the various PMEIs.

\subsection{Fungal Pathogens}

Aside from abiotic stresses, biotic stresses also pose an immense threat to plants. Since both categories of stress may occur at the same time, a common mechanism of defense is critical to survival. The cell wall itself is the first line of defense and often serves as a 
signaling mechanism alerting plants to disease through pattern recognition receptors (PRRs) and damage-associated molecular patterns (DAMPs) [89]. Pectin methylesterase (PME) has long been associated with facilitated viral movement through the association between viral-encoded mobility proteins (MPs) and PME in which PME specifically recognizes binding domains of the viral MPs [90]. Lionetti et al. (2014) hypothesized once bound, the PME-MP increase the diameter of the plasmodesmata through the loosening of the callose and thereby facilitating greater viral movement [91]. They proposed that the inhibitor, PMEI, inhibits viral movement due to the reduction in PME-MP, thereby limiting the plasmodesmata dilation [91]. While the PMEI5 in our experiments did not show a significant reduction in fungal spread, it could be due to differences in homologous traits between the various PMEs and PMEIs. In Arabidopsis, there are 71 known PMEI genes and 66 known PME genes [7,85,92]. Given the large number of PMEs, it is highly plausible that only specific PMEs interact with MPs. The ability for the cell wall to remodel in response to viral pathogens is another critical component in defense, as it increases the strength of the cell wall [93]. This process has been found to be an important mechanism of defense against a variety of viral pathogens including halo blight disease in common bean, and Potato virus [93-95]. PMEI and PME have both been found to mediate cell wall remodeling [96,97]. While this set of experiments did not specifically focus on cell wall modeling in relation to viruses, the role of PMEI5 in connection with cell wall remodeling and defense against $B$. cinerea and $C$. higginsianum should be explored further. The analysis of lesion size over the course of $5 \mathrm{dpi}$ for both $B$. cinerea and $C$. higginsianum demonstrated boron plays an integral role in resistance against both pathogens. bor 1 was significantly $(p<0.05)$ less resistant to $B$. cinerea compared to the other genotypes of interest (nip5;1, nip6;1, p35S::PMEI5 and Col-0). This is likely the result of structural changes within pectin, and more specifically RG-II, given the findings of Petrasch et al. (2019) [28]. bor1 was also significantly $(p<0.05)$ less resistant to $C$. higginsianum compared to Col-0. At 5 dpi, 100\% of the total leaf area from bor1 leaves was covered in a $B$. cinerea lesion. In comparison, leaves obtained from the other genotypes had less than $72 \%$ of their total leaf area covered lesions.

Since the BOR1 transporter is more widely expressed within the plant compared to NIP5;1 and NIP6;1, the bor1 genotype likely has a lower concentration of boron [36-38]. Thus, the reduced resistance to $B$. cinerea in bor 1 compared to nip5;1 and nip6;1 may be the result of a lower concentration of boron, as boron has been previously found to mitigate $B$. cinerea infections [31].

Similarly, at 5 dpi following inoculation with C. higginsianum, 63.1\% of the total bor1 leaf area were covered in C. higginsianum lesion, compared to an average of only $31.7 \%$ for the other genotypes of interest. In addition to having twice the total leaf area covered in a lesion at $5 \mathrm{dpi}$, as early as $1 \mathrm{dpi}$, the bor 1 total leaf area covered in a C. higginsianum lesion was over 30 times greater compared to the other genotypes of interest, suggesting boron transported through the BOR1 channel is vital in the resistance to this disease. It is well understood that boron plays a critical role in the structure of the cell wall and a mutation in BOR1 would likely reduce the concentration of boron within the cell wall [98].

The reduced function of NIP5;1 and NIP6;1, in addition to the likelihood of redundancy within the NIP family, may be responsible for differences in leaf tissue infections compared to BOR1.

Furthermore, the over-expression of PMEI1, PMEI2, PMEI10, PMEI11 and PMEI12 has been previously found to help to maintain the integrity of the cell wall in plants infected with B. cinerea [26,27]. However, the over-expression of PMEI5 in the p35S::PMEI5 did not significantly $(p>0.05)$ alter resistance to $B$. cinerea. Instead, leaves obtained from the p35S::PMEI5 had the second greatest leaf area covered in B. cinerea lesions, after bor1. The contrasting nature of these findings compared to those obtained during our experiments may be the result of variation amongst PMEIs. PMEI5 belongs to Group 3 of PMEIs while previously explored PMEIs belong to other groups [26]. Future studies should focus on gaining a greater understanding into the differences between Group 1, 2 and 3 PMEIs. 
Moreover, the more substantial lesion spread at $1 \mathrm{dpi}$ on bor 1 leaves suggests weaker cell walls within the bor1 genotype. C. higginsianum penetrates the cell wall of the host through physical pressure without the use of enzymes, unlike B. cinerea [99]. The rapid growth of lesions on bor1 leaves is indicative that $C$. higginsianum may have penetrated the cell walls with less pressure, signaling potential weakness of the bor 1 cell walls, likely the result of lower concentrations of boron and in turn, a reduction in the number of RG-II dimers. Differences in function for the BOR1 transporter in comparison to NIP5;1 and NIP6;1 may reflect the variation observed in the percentage leaf area infected. More generally, while boron has been previously reported to act as an antifungal agent for a range of species infected with Colletotrichum graminicola, to our knowledge, there are no studies exploring NIP, BOR or any other B-transporters in relation to C. higginsianum [33,34].

\section{Conclusions}

While modifications in pectin do not allow the cell wall to form an impassable barrier, these elements remain critical in the role of the cell wall as a barrier to stress. While our findings on cell wall rheology, shear force, calcium localization and analysis of water loss in pure pectin standards are indicative that "egg-box" structures and RG-II dimers likely formed, this alone was not sufficient in significantly $(p>0.05)$ improving dehydration stress tolerance. Variation was also observed with respect to resistance to the fungal pathogens of interest, suggesting that while boron and PMEI5 likely play a role in resistance to dehydration stress and fungal pathogens, the true picture appears to be far more nuanced. Overall, our findings demonstrate the cell wall is not a silver bullet to dehydration stress or fungal pathogens. Even so, the results of this study help to further our understanding of the role of the cell wall as a physical barrier to both abiotic and biotic stresses.

Supplementary Materials: The following supporting information can be downloaded at: https: / / www.mdpi.com/article/10.3390/plants11030385/s1. Figure S1: Generalized additive models showing the relationship between temperature $\left({ }^{\circ} \mathrm{C}\right)$ and pectin viscosity (Pa.S), Figure S2: Analysis of green pixels from images obtained from Allium fistulosum epidermal cell layers stained with fluorescein diacetate, Figure S3: Analysis of green pixels from images obtained from Allium cepa epidermal cell layers stained with fluorescein diacetate; Table S1: Primers used to genotype nip5;1-1, nip6;1-2 and bor1-3, Table S2: ANOVA for generalized additive models examining the relationship between temperature $\left({ }^{\circ} \mathrm{C}\right)$ and pectin viscosity (Pa.S), Table S3: ANOVA analyzing the force required to shear Allium fistulosum sheaths, Table S4: ANOVA analyzing percent water loss in Allium fistulosum and Allium cepa sheaths, Table S5: ANOVA analyzing percent water loss in pectin solutions, Table S6: Tukey's test analyzing percent water loss in pectin solutions, Table S7: ANOVA examining percent viability based on electrolyte leakage following dehydration in Allium fistulosum and Allium cepa, Table S8: Two-sample $t$-tests analyzing the intensity of green pixels following staining with fluorescein diacetate in Allium fistulosum and Allium cepa, Table S9: ANOVA analyzing lesion size following Botrytis cinerea inoculation in Arabidopsis, Table S10: Tukey test analyzing lesion size following Botrytis cinerea inoculation in Arabidopsis, Table S11: ANOVA analyzing lesion size following Colletotrichum higginsianum inoculation in Arabidopsis, Table S12: Tukey test analyzing lesion size following Colletotrichum higginsianum inoculation in Arabidopsis.

Author Contributions: Conceptualization, K.K.T.; methodology, K.K.T., C.K., Y.Z.F., S.G. and Y.W.; software, A.D.F., M.L. and J.S.; formal analysis, A.D.F., M.L. and J.S.; investigation, A.D.F., Y.Z.F., S.W. and K.K.T., resources, K.K.T., Y.W., L.Q. and S.G.; data curation, A.D.F., M.L. and J.S.; writingoriginal draft preparation, A.D.F. and K.K.T.; writing-review and editing, A.D.F. and K.K.T.; visualization, K.K.T.; supervision, K.K.T., C.K., Y.Z.F., S.G. and Y.W.; project administration, K.K.T.; funding acquisition, K.K.T. All authors have read and agreed to the published version of the manuscript.

Funding: This work was supported by the Alexander Graham Bell Canadian Graduate ScholarshipMasters (CGS-M) from the National Science and Engineering Research Council (NSERC) of Canada awarded to A.D.F, in addition to an NSERC Discovery grant awarded to K.K.T (RGPIN-2018-05853).

Institutional Review Board Statement: Not applicable.

Informed Consent Statement: Not applicable. 
Data Availability Statement: Data supporting the above findings are available within this paper and Supplementary Materials published online.

Acknowledgments: We thank Fatemeh Keivaninahr and Chi Diem Doan (University of Saskatchewan (USask), Canada) for their assistance with the rheometer and Phyllis Shand (USask, Canada) for her help with texture analysis, Na Liu (Canadian Light Source, Canada) for assistance with sample preparation for the synchrotron and Eric Lamb (USask, Canada) for guidance related to generalized additive models. We would also like to acknowledge Keristein Muller (Veristat, Canada) for the p35S::PMEI5 line and Hong Wang (USask, Canada) for assistance in ordering primers. Eldon Siemens (Agriculture Greenhouse, USask, Canada) in addition to other greenhouse staff were instrumental in the growth of Allium plants. We acknowledge fellow lab members Ian Willick and Eric Rae for support and assistance in the project. Finally, we acknowledge the University of Saskatchewan for their generosity, as this work was supported in part by various scholarships and bursaries. Part of the research described in this paper was performed at the Canadian Light Source, a national research facility of the University of Saskatchewan, which is supported by the Canada Foundation for Innovation (CFI), the Natural Sciences and Engineering Research Council (NSERC), the National Research Council (NRC), the Canadian Institutes of Health Research (CIHR), the Government of Saskatchewan, and the University of Saskatchewan. This research used resources of the Advanced Photon Source, an Office of Science User Facility operated for the U.S. Department of Energy (DOE) Office of Science by Argonne National Laboratory and was supported by the U.S. DOE under Contract No. DE-AC02-06CH11357, and the Canadian Light Source and its funding partners.

Conflicts of Interest: The authors declare no conflict of interest.

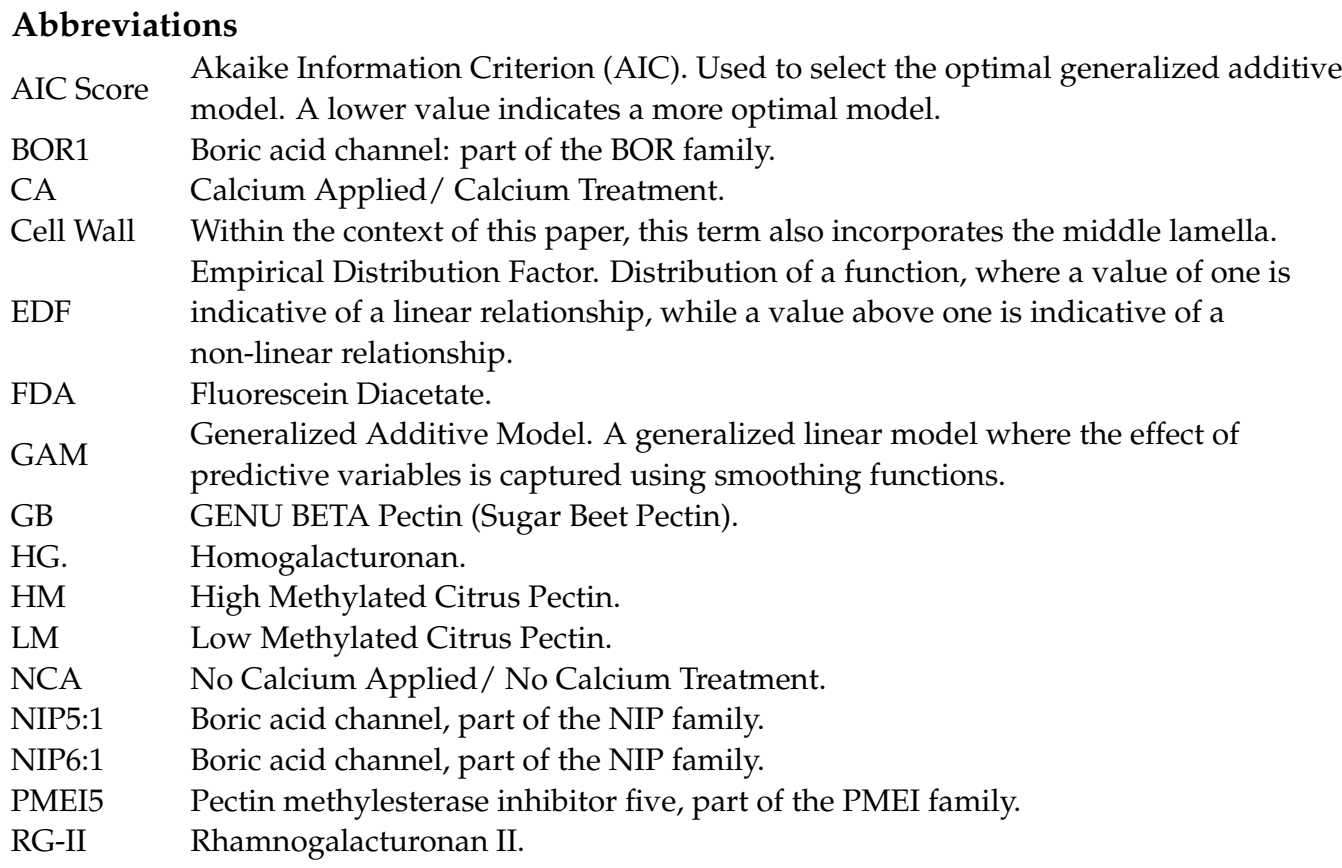

\section{References}

1. Keegstra, K. Plant Cell Walls. Plant Physiol. 2010, 154, 483-486. [CrossRef] [PubMed]

2. Houston, K.; Tucker, M.; Chowdhury, J.; Shirley, N.; Little, A. The Plant Cell Wall: A Complex and Dynamic Structure as Revealed by the Responses of Genes under Stress Conditions. Front. Plant Sci. 2016, 7, 984. [CrossRef] [PubMed]

3. Cosgrove, D.C.; Jarvis, M.C. Comparative structure and biomechanics of plant primary and secondary cell walls. Front. Plant Sci. 2012, 3, 204. [CrossRef]

4. Mohnen, D. Pectin structure and biosynthesis. Curr. Opin. Plant Biol. 2008, 11, 266-277. [CrossRef]

5. Braccini, I.; Pérez, S. Molecular Basis of $\mathrm{Ca}^{2+}$-Induced Gelation in Alginates and Pectins: The Egg-Box Model Revisited. Biomacromolecules 2001, 2, 1089-1096. [CrossRef] [PubMed]

6. Ravanat, G.; Rinaudo, M. Investigation on oligo- and polygalacturonic acids by potentiometry and circular dichroism. Biopolymers 1980, 19, 2209-2222. [CrossRef]

7. Wormit, A.; Usadel, B. The Multifaceted Role of Pectin Methylesterase Inhibitors (PMEIs). Int. J. Mol. Sci. 2018, 19, 2878. [CrossRef] 
8. Ishii, T.; Matsunaga, T.; Pellerin, P.; O’Neill, M.A.; Darvill, A.; Albersheim, P. The Plant Cell Wall Polysaccharide Rhamnogalacturonan II Self-assembles into a Covalently Cross-linked Dimer. J. Biol. Chem. 1999, 274, 13098-13104. [CrossRef]

9. Matoh, T. Boron in Plant Cell Walls. In Plant and Soil; Kluwer Academic Publishers: Berlin/Heidelberg, Germany, 1997; Volume 193, pp. 59-70. Available online: https://link.springer.com/content/pdf/10.1023\%2FA\%3A1004207824251.pdf (accessed on 10 April 2021). [CrossRef]

10. Fleischer, A.; O'Neill, M.A.; Ehwald, R. The Pore Size of Non-Graminaceous Plant Cell Walls Is Rapidly Decreased by Borate Ester Cross-Linking of the Pectic Polysaccharide Rhamnogalacturonan II. Plant Physiol. 1999, 121, 829-838. [CrossRef]

11. Ryden, P.; Sugimoto-Shirasu, K.; Smith, A.C.; Findlay, K.; Reiter, W.-D.; McCann, M.C. Tensile Properties of Arabidopsis Cell Walls Depend on Both a Xyloglucan Cross-Linked Microfibrillar Network and Rhamnogalacturonan II-Borate Complexes. Plant Physiol. 2003, 132, 1033-1040. [CrossRef] [PubMed]

12. Willats, W.; Orfila, C.; Limberg, G.; Buchholt, H.C.; van Alebeek, G.-J.W.M.; Voragen, A.G.J.; Marcus, S.E.; Christensen, T.M.I.E.; Mikkelsen, J.D.; Murray, B.S.; et al. Modulation of the Degree and Pattern of Methyl-esterification of Pectic Homogalacturonan in Plant Cell Walls. J. Biol. Chem. 2001, 276, 19404-19413. [CrossRef] [PubMed]

13. Thor, K. Calcium-Nutrient and Messenger. Front. Plant Sci. 2019, 10, 440. [CrossRef] [PubMed]

14. Alberts, B.; Johnson, A.; Lewis, J.; Raff, M.; Roberts, K.; Walter, P. The Plant Cell Wall. 2002. Available online: https://www.ncbi. nlm.nih.gov/books/NBK26928/ (accessed on 10 April 2021).

15. White, P.B.; Wang, T.; Park, Y.B.; Cosgrove, D.J.; Hong, M. Water-Polysaccharide Interactions in the Primary Cell Wall of Arabidopsis thaliana from Polarization Transfer Solid-State NMR. J. Am. Chem. Soc. 2014, 136, 10399-10409. [CrossRef]

16. Ha, M.-A.; Apperley, D.C.; Jarvis, M.C. Molecular Rigidity in Dry and Hydrated Onion Cell Walls. Plant Physiol. 1997, 115, 593-598. [CrossRef]

17. Mohnen, D.; Engle, K.; Amos, R.; Yan, J.Y.; Glushka, J.; Atmodjo, M.; Tan, L.; Moremen, K.W. A new model for pectin structural synthesis. In Proceedings of the Plant Cell Wall Biology 2021, Sapporo, Japan, 27 June-1 July 2021; p. 59.

18. Konno, H.; Yamasaki, Y.; Sugimoto, M.; Takeda, K. Differential changes in cell wall matrix polysaccharides and glycosidehydrolyzing enzymes in developing wheat seedlings differing in drought tolerance. J. Plant Physiol. 2008, 165, 745-754. [CrossRef]

19. Leucci, M.R.; Lenucci, M.S.; Piro, G.; Dalessandro, G. Water stress and cell wall polysaccharides in the apical root zone of wheat cultivars varying in drought tolerance. J. Plant Physiol. 2008, 165, 1168-1180. [CrossRef]

20. Piro, G.; Leucci, M.R.; Waldron, K.; Dalessandro, G. Exposure to water stress causes changes in the biosynthesis of cell wall polysaccharides in roots of wheat cultivars varying in drought tolerance. Plant Sci. 2003, 165, 559-569. [CrossRef]

21. Herburger, K.; Xin, A.; Holzinger, A. Homogalacturonan Accumulation in Cell Walls of the Green Alga Zygnema sp. (Charophyta) Increases Desiccation Resistance. Front. Plant Sci. 2019, 10, 540. [CrossRef]

22. Abdel-Motagally, F.; El-Zohri, M. Improvement of wheat yield grown under drought stress by boron foliar application at different growth stages. J. Saudi Soc. Agric. Sci. 2018, 17, 178-185. [CrossRef]

23. Karim, M.R.; Zhang, Y.Q.; Zhao, R.R.; Chen, X.P.; Zhang, F.S.; Zou, C.Q. Alleviation of drought stress in winter wheat by late foliar application of zinc, boron, and manganese. J. Plant Nutr. Soil Sci. 2012, 175, 142-151. [CrossRef]

24. Panter, P.E.; Kent, O.; Dale, M.; Smith, S.J.; Skipsey, M.; Thorlby, G.; Cummins, I.; Ramsay, N.; Begum, R.A.; Sanhueza, D.; et al MUR1-mediated cell-wall fucosylation is required for freezing tolerance in Arabidopsis thaliana. New Phytol. 2019, 224, 1518-1531. [CrossRef] [PubMed]

25. Lionetti, V.; Raiola, A.; Camardella, L.; Giovane, A.; Obel, N.; Pauly, M.; Favaron, F.; Cervone, F.; Bellincampi, D. Overexpression of Pectin Methylesterase Inhibitors in Arabidopsis Restricts Fungal Infection by Botrytis cinerea. Plant Physiol. 2007, 143, 1871-1880. [CrossRef] [PubMed]

26. Lionetti, V.; Fabri, E.; De Caroli, M.; Hansen, A.R.; Willats, W.G.; Piro, G.; Bellincampi, D. Three Pectin Methylesterase Inhibitors Protect Cell Wall Integrity for Arabidopsis Immunity to Botrytis. Plant Physiol. 2017, 173, 1844-1863. [CrossRef]

27. Raiola, A.; Lionetti, V.; Elmaghraby, I.; Immerzeel, P.; Mellerowicz, E.J.; Salvi, G.; Cervone, F.; Bellincampi, D. Pectin Methylesterase Is Induced in Arabidopsis upon Infection and Is Necessary for a Successful Colonization by Necrotrophic Pathogens. Mol. Plant-Microbe Interact. 2011, 24, 432-440. [CrossRef] [PubMed]

28. Petrasch, S.; Silva, C.J.; Mesquida-Pesci, S.D.; Gallegos, K.; van den Abeele, C.; Papin, V.; Fernandez-Acero, F.J.; Knapp, S.J.; Blanco-Ulate, B. Infection Strategies Deployed by Botrytis cinerea, Fusarium acuminatum, and Rhizopus stolonifer as a Function of Tomato Fruit Ripening Stage. Front. Plant Sci. 2019, 10, 223. [CrossRef]

29. Engelsdorf, T.; Will, C.; Hofmann, J.; Schmitt, C.; Merritt, B.B.; Rieger, L.; Frenger, M.S.; Marschall, A.; Franke, R.B.; Pattathil, S.; et al. Cell wall composition and penetration resistance against the fungal pathogenColletotrichum higginsianumare affected by impaired starch turnover in Arabidopsis mutants. J. Exp. Bot. 2016, 68, 701-713. [CrossRef]

30. Qin, G.; Zong, Y.; Chen, Q.; Hua, D.; Tian, S. Inhibitory effect of boron against Botrytis cinerea on table grapes and its possible mechanisms of action. Int. J. Food Microbiol. 2010, 138, 145-150. [CrossRef]

31. Wójcik, P.; Lewandowski, M. Effect of Calcium and Boron Sprays on Yield and Quality of "Elsanta" Strawberry. J. Plant Nutr. 2003, 26, 671-682. [CrossRef]

32. Shi, X.-Q.; Li, B.-Q.; Qin, G.-Z.; Tian, S.-P. Antifungal Activity and Possible Mode of Action of Borate Against Colletotrichum gloeosporioides on Mango. Plant Dis. 2011, 95, 63-69. [CrossRef]

33. Shi, X.; Li, B.; Qin, G.; Tian, S. Mechanism of antifungal action of borate against Colletotrichum gloeosporioides related to mitochondrial degradation in spores. Postharvest Biol. Technol. 2012, 67, 138-143. [CrossRef] 
34. Palta, J.P.; Levitt, J.; Stadelmann, E.J. Freezing Injury in Onion Bulb Cells. Plant Physiol. 1977, 60, 393-397. [CrossRef] [PubMed]

35. Tanino, K.K.; Kobayashi, S.; Hyett, C.; Hamilton, K.; Liu, J.; Li, B.; Borondics, F.; Pedersen, T.; Tse, J.; Ellis, T.; et al. Allium fistulosumas a novel system to investigate mechanisms of freezing resistance. Physiol. Plant. 2012, 147, 101-111. [CrossRef] [PubMed]

36. TAIR. Locus: AT1G80760. 2013. Available online: https://www.arabidopsis.org/servlets /TairObject?name=at1g80760\&type= locus (accessed on 10 April 2021).

37. TAIR. Locus: AT4G10380. 2015. Available online: https://www.arabidopsis.org/servlets /TairObject?type=locus\&name=At4g103 80 (accessed on 10 April 2021).

38. TAIR. Locus: AT2G47160. 2021. Available online: https:/ /www.arabidopsis.org/servlets /TairObject?name=AT2G47160\&type= locus (accessed on 10 April 2021).

39. Müller, K.; Levesque-Tremblay, G.; Bartels, S.; Weitbrecht, K.; Wormit, A.; Usadel, B.; Haughn, G.; Kermode, A.R. Demethylesterification of Cell Wall Pectins in Arabidopsis Plays a Role in Seed Germination. Plant Physiol. 2012, 161, 305-316. [CrossRef] [PubMed]

40. Edwards, K.; Johnstone, C.; Thompson, C. A simple and rapid method for the preparation of plant genomic DNA for PCR analysis. Nucleic Acids Res. 1991, 19, 1349. [CrossRef] [PubMed]

41. Wang, S.; Wen, R.; Shi, X.; Lambrecht, A.; Wang, H.; Xiao, W. RAD5a and REV3 function in two alternative pathways of DNA-damage tolerance in Arabidopsis. DNA Repair 2011, 10, 620-628. [CrossRef]

42. Hutton, B.; (TIC Gums, White Marsh, MD, USA). Personal Communication, 2019.

43. Meyers, D.; (CP Kelco, Atlanta, GA, USA). Personal Communication, 2019.

44. Yapo, B.M.; Lerouge, P.; Thibault, J.-F.; Ralet, M.-C. Pectins from citrus peel cell walls contain homogalacturonans homogenous with respect to molar mass, rhamnogalacturonan I and rhamnogalacturonan II. Carbohydr. Polym. 2007, 69, 426-435. [CrossRef]

45. Mankarios, A.T.; Hall, M.A.; Jarvis, M.C.; Threlfall, D.R.; Friend, J. Cell wall polysaccharides from onions. Phytochemistry 1980, 19, 1731-1733. [CrossRef]

46. Willick, I.R. The Mechanism of Freezing Resistance in Cold-Acclimated Winter Wheat and Rye Crowns. Ph.D. Thesis, The University of Saskatchewan, Saskatoon, SK, Canada, 2018.

47. Flint, H.L.; Boyce, B.R.; Beattie, D.J. Index of injury-A useful expression of freezing injury to plant tissues as determined by the electrolytic method. Can. J. Plant Sci. 1967, 47, 229-230. [CrossRef]

48. Banik, P.; Zeng, W.; Tai, H.; Bizimungu, B.; Tanino, K. Effects of drought acclimation on drought stress resistance in potato (Solanum tuberosum L.) genotypes. Environ. Exp. Bot. 2016, 126, 76-89. [CrossRef]

49. Stobbs, J.; (Canadian Light Source, Saskatoon, SK, Canada). Personal Communication, 2021.

50. Sole, V.A.; Papillon, E.; Cotte, M.; Walter, P.; Susini, J. A multiplatform code for the analysis of energy-dispersive X-ray fluorescence spectra. Spectrochim. Acta Part B At. Spectrosc. 2007, 62, 63-68. [CrossRef]

51. Liu, G.; Ji, Y.; Bhuiyan, N.H.; Pilot, G.; Selvaraj, G.; Zou, J.; Wei, Y. Amino Acid Homeostasis Modulates Salicylic Acid-Associated Redox Status and Defense Responses inArabidopsis. Plant Cell 2010, 22, 3845-3863. [CrossRef] [PubMed]

52. Liu, G.; Kennedy, R.; Greenshields, D.L.; Peng, G.; Forseille, L.; Selvaraj, G.; Wei, Y. Detached and Attached Arabidopsis Leaf Assays Reveal Distinctive Defense Responses Against Hemibiotrophic Colletotrichum spp. Mol. Plant-Microbe Interact. 2007, 20, 1308-1319. [CrossRef] [PubMed]

53. Wang, S.; Li, Q.; Zhao, L.; Fu, S.; Qin, L.; Wei, Y.; Fu, Y.-B.; Wang, H. Arabidopsis UBC22, an E2 able to catalyze lysine-11 specific ubiquitin linkage formation, has multiple functions in plant growth and immunity. Plant Sci. 2020, 297, 110520. [CrossRef] [PubMed]

54. Wood, S.N. Generalized Additive Models: An Introduction with R, 2nd ed.; CRC Press: Boca Raton, FL, USA, 2017.

55. Wood, S. Package ' $m g c v^{\prime}$; 1.8-38. CRAN, 2021. Available online: https://cran.r-project.org/web/packages $/ \mathrm{mgcv} / \mathrm{mgcv} . \mathrm{pdf}$ (accessed on 20 April 2021).

56. Adler, D.; Murdoch, D. rgl: 3D Visualization Using OpenGL. CRAN. 4 March 2021. Available online: https://rdrr.io/cran/rgl/ (accessed on 20 April 2021).

57. Fasiolo, M.; Nedellec, R.; Goude, Y.; Capezza, C.; Wood, S. mgcViz: Visualisations for Generalized Additive Models; 0.1.9. CRAN, 2020. Available online: https:/ / cran.r-project.org/web/packages/mgcViz/mgcViz.pdf (accessed on 20 April 2021).

58. Wickham, H.; Hester, J.; Chang, W. Devtools: Tools to Make Developing R Packages Easier; 2.4.3. CRAN, 2021. Available online: https://cran.r-project.org/web/packages/devtools/devtools.pdf (accessed on 20 April 2021).

59. Polymer Solutions News Team. Metal Properties: Hardness, Toughness, \& Strength. 2015. Available online: https://www. polymersolutions.com/blog/defining-metal-properties/ (accessed on 20 April 2021).

60. Ritchie, R.O. The conflicts between strength and toughness. Nat. Mater. 2011, 10, 817-822. [CrossRef] [PubMed]

61. O'Neill, M.A.; Ishii, T.; Albersheim, P.; Darvill, A.G. Rhamnogalacturonan ii: Structure and function of a borate cross-linked cell wall pectic polysaccharide. Annu. Rev. Plant Biol. 2004, 55, 109-139. [CrossRef]

62. Hu, W.; Tian, S.B.; Di, Q.; Duan, S.H.; Dai, K. Effects of exogenous calcium on mesophyll cell ultrastructure, gas exchange, and photosystem II in tobacco (Nicotiana tabacum Linn.) under drought stress. Photosynthetica 2018, 56, 1204-1211. [CrossRef]

63. Hosseini, S.A.; Réthoré, E.; Pluchon, S.; Ali, N.; Billiot, B.; Yvin, J.-C. Calcium Application Enhances Drought Stress Tolerance in Sugar Beet and Promotes Plant Biomass and Beetroot Sucrose Concentration. Int. J. Mol. Sci. 2019, 20, 3777. [CrossRef] 
64. Khushboo; Bhardwaj, K.; Singh, P.; Raina, M.; Sharma, V.; Kumar, D. Exogenous application of calcium chloride in wheat genotypes alleviates negative effect of drought stress by modulating antioxidant machinery and enhanced osmolyte accumulation. Vitr. Cell. Dev. Biol. Anim. 2018, 54, 495-507. [CrossRef]

65. Schatzberg, P. Molecular diameter of water from solubility and diffusion measurements. J. Phys. Chem. 1967, 71, 4569-4570. [CrossRef]

66. Liu, J. Temperature-Mediated Alterations of the Plant Apoplast as a Mechanism of Intracellular Freezing Stress Avoidance; University of Saskatchewan: Saskatoon, SK, Canada, 2015; Available online: https:/ /harvest.usask.ca/handle/10388/ETD-2015-10-2290 (accessed on 20 April 2021).

67. Trewavas, A.; Knight, M. Mechanical signalling, calcium and plant form. In Signals and Signal Transduction Pathways in Plants; Springer: Dordrecht, The Netherlands, 1994; pp. 93-105. [CrossRef]

68. Knight, H.; Trewavas, A.J.; Knight, M. Calcium signalling in Arabidopsis thaliana responding to drought and salinity. Plant J 1997, 12, 1067-1078. [CrossRef] [PubMed]

69. Wang, J.-P.; Munyampundu, J.-P.; Xu, Y.-P.; Cai, X.-Z. Phylogeny of Plant Calcium and Calmodulin-Dependent Protein Kinases (CCaMKs) and Functional Analyses of Tomato CCaMK in Disease Resistance. Front. Plant Sci. 2015, 6, 1075. [CrossRef] [PubMed]

70. Bender, K.W.; Snedden, W.A. Calmodulin-Related Proteins Step Out from the Shadow of Their Namesake. Plant Physiol. 2013, 163, 486-495. [CrossRef] [PubMed]

71. Luan, S. The CBL-CIPK network in plant calcium signaling. Trends Plant Sci. 2009, 14, 37-42. [CrossRef] [PubMed]

72. Yang, T.; Poovaiah, B. Calcium/calmodulin-mediated signal network in plants. Trends Plant Sci. 2003, 8, 505-512. [CrossRef]

73. Cheng, S.-H.; Willmann, M.R.; Chen, H.-C.; Sheen, J. Calcium Signaling through Protein Kinases. The Arabidopsis CalciumDependent Protein Kinase Gene Family. Plant Physiol. 2002, 129, 469-485. [CrossRef]

74. Hepler, P.K. Calcium: A Central Regulator of Plant Growth and Development. Plant Cell 2005, 17, 2142-2155. [CrossRef]

75. Burstrom, H.G. Calcium and plant growth. Biol. Rev. 1968, 43, 287-316. [CrossRef]

76. Jones, R.G.W.; Lunt, O.R. The function of calcium in plants. Bot. Rev. 1967, 33, 407-426. [CrossRef]

77. Arora, R. Mechanism of freeze-thaw injury and recovery: A cool retrospective and warming up to new ideas. Plant Sci. 2018, 270, 301-313. [CrossRef]

78. Moore, J.P.; Vicré-Gibouin, M.; Farrant, J.M.; Driouich, A. Adaptations of higher plant cell walls to water loss: Drought vs desiccation. Physiol. Plant. 2008, 134, 237-245. [CrossRef] [PubMed]

79. Burke, M.J.; Gusta, L.V.; Quamme, A.H.; Weiser, C.J.; Li, P.H. Freezing and Injury in Plants. Annu. Rev. Plant Physiol. 1976, 27, 507-528. [CrossRef]

80. Oertli, J.J. Negative Turgor Pressures in Plant Cells. Z. Für Pflanz. Und Bodenkd. 1986, 149, 60-67. [CrossRef]

81. Oertli, J.J.; Lips, S.H.; Agami, M. The strength of sclerophyllous cells to resist collapse due to negative turgor pressure. Acta Oecol. 1990, 11, 281-289.

82. Aydin, M.; Tombuloglu, G.; Sakcali, M.S.; Hakeem, K.R.; Tombuloglu, H. Boron Alleviates Drought Stress by Enhancing Gene Expression and Antioxidant Enzyme Activity. J. Soil Sci. Plant Nutr. 2019, 19, 545-555. [CrossRef]

83. Naeem, M.; Ahmad, R.; Ahmad, R.; Ashraf, M.Y.; Ihsan, M.Z.; Nawaz, F.; Athar, H.-U.; Abbas, H.T.; Abdullah, M. Improving drought tolerance in maize by foliar application of boron: Water status, antioxidative defense and photosynthetic capacity. Arch Agron. Soil Sci. 2017, 64, 626-639. [CrossRef]

84. Xue, C.; Guan, S.-C.; Chen, J.-Q.; Wen, C.-J.; Cai, J.-F.; Chen, X. Genome wide identification and functional characterization of strawberry pectin methylesterases related to fruit softening. BMC Plant Biol. 2020, 20, 13-17. [CrossRef]

85. Wang, M.; Yuan, D.; Gao, W.; Li, Y.; Tan, J.; Zhang, X. A Comparative Genome Analysis of PME and PMEI Families Reveals the Evolution of Pectin Metabolism in Plant Cell Walls. PLoS ONE 2013, 8, e72082. [CrossRef]

86. An, S.H.; Sohn, K.H.; Choi, H.W.; Hwang, I.S.; Lee, S.C.; Hwang, B.K. Pepper pectin methylesterase inhibitor protein CaPMEI1 is required for antifungal activity, basal disease resistance and abiotic stress tolerance. Planta 2008, 228, 61-78. [CrossRef]

87. Amsbury, S.; Hunt, L.; Elhaddad, N.; Baillie, A.; Lundgren, M.; Verhertbruggen, Y.; Scheller, H.; Knox, P.; Fleming, A.J.; Gray, J.E. Stomatal Function Requires Pectin De-methyl-esterification of the Guard Cell Wall. Curr. Biol. 2016, 26, 2899-2906. [CrossRef]

88. Yang, W.; Ruan, M.; Xiang, M.; Deng, A.; Du, J.; Xiao, C. Overexpression of a pectin methylesterase gene PtoPME35 from Populus tomentosa influences stomatal function and drought tolerance in Arabidopsis thaliana. Biochem. Biophys. Res. Commun. 2019, 523, 416-422. [CrossRef] [PubMed]

89. Bacete, L.; Mélida, H.; Miedes, E.; Molina, A. Plant cell wall-mediated immunity: Cell wall changes trigger disease resistance responses. Plant J. 2018, 93, 614-636. [CrossRef] [PubMed]

90. Chen, M.-H.; Sheng, J.; Hind, G.; Handa, A.K.; Citovsky, V. Interaction between the tobacco mosaic virus movement protein and host cell pectin methylesterases is required for viral cell-to-cell movement. EMBO J. 2000, 19, 913-920. [CrossRef] [PubMed]

91. Lionetti, V.; Raiola, A.; Cervone, F.; Bellincampi, D. How do pectin methylesterases and their inhibitors affect the spreading of tobamovirus? Plant Signal. Behav. 2014, 9, e972863. [CrossRef]

92. Bethke, G.; Grundman, R.E.; Sreekanta, S.; Truman, W.; Katagiri, F.; Glazebrook, J. Arabidopsis PECTIN METHYLESTERASEs Contribute to Immunity against Pseudomonas syringae. Plant Physiol. 2013, 164, 1093-1107. [CrossRef]

93. De la Rubia, A.; Mélida, H.; Centeno, M.; Encina, A.; García-Angulo, P. Immune Priming Triggers Cell Wall Remodeling and Increased Resistance to Halo Blight Disease in Common Bean. Plants 2021, 10, 1514. [CrossRef] 
94. Otulak-Kozieł, K.; Kozieł, E.; Lockhart, B.E.L.; Bujarski, J.J. The Expression of Potato Expansin A3 (StEXPA3) and Extensin4 (StEXT4) Genes with Distribution of StEXPAs and HRGPs-Extensin Changes as an Effect of Cell Wall Rebuilding in Two Types of PVYNTN-Solanum tuberosum Interactions. Viruses 2020, 12, 66. [CrossRef]

95. Otulak-Kozieł, K.; Kozieł, E.; Lockhart, B.E.L. Plant Cell Wall Dynamics in Compatible and Incompatible Potato Response to Infection Caused by Potato Virus Y (PVYNTN). Int. J. Mol. Sci. 2018, 19, 862. [CrossRef]

96. Willats, W.G.; McCartney, L.; Mackie, W.; Knox, J.P. Pectin: Cell biology and prospects for functional analysis. Plant Mol. Biol. 2001, 47, 9-27. [CrossRef]

97. Baluška, F.; Liners, F.; Hlavačka, A.; Schlicht, M.; Van Cutsem, P.; McCurdy, D.W.; Menzel, D. Cell wall pectins and xyloglucans are internalized into dividing root cells and accumulate within cell plates during cytokinesis. Protoplasma 2005, 225, 141-155. [CrossRef]

98. Brown, P.H.; Bellaloui, N.; Wimmer, M.A.; Bassil, E.S.; Ruiz, J.; Hu, H.; Pfeffer, H.; Dannel, F.; Römheld, V. Boron in Plant Biology. Plant Biol. 2002, 4, 205-223. [CrossRef]

99. Yan, Y.; Yuan, Q.; Tang, J.; Huang, J.; Hsiang, T.; Wei, Y.; Zheng, L. Colletotrichum higginsianum as a Model for Understanding Host-Pathogen Interactions: A Review. Int. J. Mol. Sci. 2018, 19, 2142. [CrossRef] [PubMed] 